\title{
PEDAGÓguSOK PÁlYAKÉPE, A TANÁRKÉPZÉSSEL VALÓ ELÉGEDETTSÉGÜK ÉS NEHÉZSÉGEIK
}

\author{
N. KOLlÁR KATALIN \\ az Eötvös Loránd Tudományegyetem Pedagógiai és Pszichológiai Karának \\ egyetemi docense \\ kollar.katalin@ppk.elte.hu
}

\begin{abstract}
Tanulmányunkban egy gyakorló pedagógusok körében végzett kérdöives vizsgáltról számolunk be, melyet a pedagógus pálya jellemzőivel, a feladatok végzéséhez szükséges személyiség jellemzökkel és a pedagógusképzéssel kapcsolatban végeztünk. A vizsgálat 241 pedagógus eredményeit mutatja be, óvónötöl a középiskolai tanárig. A vizsgálat bemutatja a pedagógusok véleménye szerint legfontosabb feladatköröket, az ezekhez szükséges személyiségtulajdonságokat, és hogy ezeket a tulajdonságokat mennyire tartják fejleszthetönek. A pedagógusképzés szempontjából három fó kérdést vizsgáltunk: mennyire fejlesztette ezeket a kívánatos tulajdonságokat a képzés, milyen mértékben készitett fel az egyes feladatkörökre, és milyen hatékonysága van a különbözö képzési formáknak. A fö problémákat a pedagógusok a magatartási és tanulási problémás diákokkal való bánásmódban, elsösorban az órán kívüli nevelésben és a tanári kiegyensúlyozottság és empátia elsajátításában látják. A képzésben az interaktív és gyakorlat centrikus módszereket érzik leghatékonyabbnak.
\end{abstract}

A bolognai folyamat során átalakuló felsőoktatás keretében a pedagógusképzés is átalakul, s ez a változás egyben nagy lehetőségeket is rejt magában. Módot ad a célok és módszerek újragondolására, az eddigi gyakorlat erősségeinek felmérésére és a hiányosságok korrekciójára. A reformtörekvésekben a kompetencia alapú képzés a leghangsúlyosabb célkitüzés. A jelen tanulmányunk annak a kutatásnak az eredményeit mutatja be, amelyet a pedagógusképzés feladatköreinek és képzési formáinak tervezése során végeztünk el. A tanárok pályaképével és a képzéses való elégedettségükkel kapcsolatos vizsgálatot célzottan ennek az előkészítő munkának a segítésére terveztük.

Már nagymértékben benne járunk a reformok előkészítésében, sőt 2006 őszén országosan elindultak azok az első BA/Bsc évfolyamok, amelynek hallgatói már az új típusú pedagógusképzésben vesznek részt. Így a keretek már adottak, és a képzés első fázisában az ELTE Pedagógiai és Pszichológiai Karán már harmadik éve dolgozunk azokkal a diákokkal, akik a 10 kredites „tanári előkészítő” modul tantárgyait felvették. Az új, a jövőben az MA szinten folyó tanárképzés tartalmi kidolgozása is megtörtént, és ehhez felhasználtuk a jelen tanulmányban bemutatásra kerülö kutatásaink eredményeit is. 


\section{Vizsgálatok a pedagógus pályával kapcsolatban}

A pedagógusképzés tervezéséhez a pedagógus pályával kapcsolatos vizsgálatok jó kiindulási támpontokkal szolgálhatnak számunkra, mivel kijelölik az elérendő célokat, valamint információkat nyújtanak arról, hogy milyen kihívások elé állítja a leendő pedagógusokat ez a foglalkozás.

\section{Az ideális pedagógus tulajdonságai}

Az egyik visszatérően vizsgált kérdéskör a pedagógusokkal szembeni elvárások, az „ideális tanár” kérdéskörében ragadható meg. Mind a pedagógusok, mind a diákok és szülök körében születettek olyan vizsgálatok, amelyek a hatékony pedagógusi tulajdonságokat kutatják (Gordon, 1990; Hamachek, D., 1990; Szabó Éva, 1999; Boreczky Ágnes, 1997; Szabó Éva, 2006). Három csoportban lehet megragadni a fontos tulajdonságokat, a személyiségvonásokban, melyek közül a megértés, türelem emelkedik ki leggyakrabban, az intellektuális dimenzióban - a tanított tantárggyal kapcsolatos szaktudásban, és a tanítási módszerek és készségek területén - jól magyaráz stb. (N. Kollár, Szabó, 2004). Ezek közül különösen tanulságosak számunkra a magyar iskolai környezetben végzett vizsgálatok. Két szempontból is informatívak ezek az eredmények, egyrészt, mert a pedagógusokkal szembeni elvárásokról adnak képet, másrészt a különböző gyerekek igényeit mutatják, összehasonlító képet adva az eltérő diákok hozzáállásáról - az egyéni bánásmód szükségességéről. Például Imre Anna cigány szakmunkás tanulók körében végzett vizsgálata azt mutatta, hogy a hátrányos helyzetü, roma származású tanulók jobban igénylik a személyességet, közvetlenséget, az egyéni odafigyelést és azt is, hogy a pedagógus tartson fegyelmet (Imre, 1999). Az általános iskolás és a középiskolás diákok véleményét összehasonlítva a szaktudás növekvő szerepét és a személyesség csökkenését tapasztaljuk (Martonné Tamás, N. Kollár, 2001; N. Kollár, Szabó 2004).

\section{A kezdő pedagógus problémái}

A pályakezdéssel kapcsolatos vizsgálatok fókuszában általában a kezdő és gyakorlott pedagógus közti különbségek állnak. A vizsgálatok abból a feltételezésből indulnak ki, hogy a frissen végzett pedagógusokat a gyakorlat hiányában, a tanítás más jellegü nehézségek elé állítja, mint a gyakorlottakat. Ebben elsősorban a reflektivitás alacsony szintje, és a pillanatnyi helyzethez való alkalmazkodás, a differenciált bánásmód hiánya játszik szerepet (Szivák 1998). A képzés szempontjából ezek az eredmények ki is jelölik a feladatokat, a konkrét nehézségek feltárása lehetővé teszi a célzott feladatok tervezését, amelyekkel a pályakezdés nehézségei csökkenthetőek, ha nem is várhatjuk, hogy teljesen megszünjenek.

Érdekes ebből a szempontból B. L. Cooke és K. N. Pang Hon Kong-i vizsgálata, melyben képzett, részben képzett és szakképzetlen kezdő pedagógusokat hason- 
lított össze (Cooke és Pang 1991). Ez a vizsgálat azért különleges számunkra, mert a vizsgálat színhelyén, Hong Kongban alkalmaznak szakképesítés nélküli tanárokat is, így közvetlenebbül mérhető a szakképzés hatása. A 129 kezdő pedagógus tapasztalatait, nehézségeit, igényeit, munkához való alkalmazkodását, és azt vizsgálták, milyen mértékben gondolkodnak iskolaváltáson vagy pályaelhagyáson. A képzett és nem képzett pedagógusok egyaránt a Hong Kong-i egyetemen szereztek diplomát, a képzett csoport ezután egyéves képzés keretében kapott pedagógus végzettséget. A részben képzettek egy hetes intenzív tréningben részesültek. A vizsgálat szerint lényeges különbségek találhatók a képzettek javára. Ez a csoport kevésbé találta kimerítőnek az első évet, közülük csak 33\% nyilatkozott úgy, hogy ez számára fárasztó vagy „,nagyon fárasztó” volt, a részben képzetteknél ez az arány $56 \%$, a képzetleneknél $50 \%$. A kezdeti elvárásaik reálisabbak voltak az iskolával szemben, kevesebb problémáról számoltak be, eredményesebben oldották meg a konfliktusaikat, nagyobb mértékben tudtak információkat szerezni és alkalmasabbnak, valamint motiváltabbnak érezték magukat az első év végén arra, hogy a pályán maradjanak.

\section{Vizsgálatok a pedagógusi munka körülményeivel és a pedagógusok jellemzőivel kapcsolatban}

A képzés szempontjából fontos információkat tartalmaznak azok a vizsgálatok, amelyek a pedagógusok munkakörülményeit (Salamon, Széphalmi, 1988; Papp, 2001), és a jellemző munkamódszereiket, attitüdjeiket és nézeteit tárja fel (Golnhofer, Falus, 2001). A hazai vizsgálatok a módszertani kultúra tekintetében a frontális munka túlsúlyát mutatják. Az interaktív módszerek ismerete is kívánni valókat hagy maga után, de különösen fontos tanulság, hogy ezek ismerete nem járt együtt rendszeres alkalmazásukkal.

A nézetek és az alkalmazott módszerek összefüggésének vizsgálatára módszertanilag is szép példa Wolters és Daugherty tanulmánya a pedagógusok hatékonyságról vallott felfogásával kapcsolatban az Egyesült Államokban (Wolters, Daugherty, 2007). A szerzők 1024 pedagógus válaszai alapján elemezték az osztálytermi munkát befolyásoló célstruktúra és a személyes hatékonyság összetevőit. A célok tekintetében a teljesítmény elérését és a diákok egyéni felkészítésének hatékonyságát, míg a személyes hatékonyság tekintetében a tanítást, az osztálytermi folyamatok irányítását, és a gyerekek személyiségére való hatni tudást különítették el vizsgálati dimenzióként.

A pedagógusok személyes hatékonysága növekedett a tanítási tapasztalatok hatására, bár ezt a különbséget föként a pályakezdők és az öt-tíz éve tanítók közt mutatták ki. Az eredményeket két szempontból fenntartással érdemes kezelni. Egyrészt ez a hatás csekély, másrészt a vizsgálat nem tudta kontrollálni annak hatását, hogy a pályaelhagyók éppen az alacsonyabb önértékelésủek közül kerülnek ki, 
ezért a hosszabb ideje tanítók önértékelés átlaga nő. A gyakorlattal növekvő énhatékonyság-érzést további két tényezővel is magyarázzák, a célzott tematikájú pedagógus-továbbképzéseknek és annak, hogy a pályán eltöltött idő módot ad a hatékony pedagógus kollegáktól való utánzásos tanulásra.

A vizsgálatban összefüggést találtak a tanítás céljai és az oktatott diákok életkora, valamint a személyes hatékonyság dimenziói és az osztálytermi célok közt. Két tanítási célt vizsgáltak, a készségfejlesztést, a tanulók önmagukhoz mért fejlesztését, valamint a minél nagyobb teljesítmény elérését. Azt találták, hogy a pedagógusok énhatékonyság-érzésének különböző aspektusai szorosan együtt járnak (a korrelációs értékek $0,68-0,69$ ), és mindhárom énhatékonyság dimenzió összefüggést mutatott a készségfejlesztéssel, mint tanítási céllal. A tanítókat nagyobb énhatékonyság-érzés jellemezte, és fontosabbnak tartották a készségfejlesztést, mint tanítási célt. A felsős és középiskolai tanárok közt nem találtak különbséget a tanítási célok tekintetében. A vizsgálat érdekes megállapítása, hogy a képességfejlesztés és teljesítményre törekvés nem zárja ki egymást, nem egy dimenzió végpontjaiként képzelendők el, hanem kis mértékben $\left(\mathrm{r}=0,25^{* *}\right)$ egymással is korrelálnak.

Vizsgálták továbbá a képzettségi szint szerepét is, de nem találtak különbséget sem az önértékelés, sem a tanítási célok tekintetében.

\section{Pedagógusok véleménye a pedagógus pályával és a saját képzésükkel kapcsolatban}

A bolognai folyamat keretében megújítandó tanári képzés irányvonalának kialakításához és a korábbi pedagógusképzés gyakorlatának felmérésére 2006-ban végeztünk vizsgálatot a pályán levő pedagógusok körében. Kérdésfeltevésünk arra irányult, hogy melyek a fô nehézségek a pedagógusok véleménye szerint, valamint, hogy mik a képzés erősségei és gyengeségei.

A vizsgálat első szakaszában interjúkat vettünk fel gyakorló pedagógusokkal. Az interjú vezérfonalának összeállításában és az interjúk készítésében és feldolgozásában az ELTE PPK Iskolai Pszichológiai Intézeti Szakcsoportjában dolgozó kollégák ${ }^{1}$ vettek részt. Az interjúk alapján állítottuk össze a vizsgálat kérdéseit.

Kérdésfeltevésünk négy témakörre irányult:

- Milyen feladatkörök ellátását kívánja meg a mai iskola a pedagógusoktól?

- Milyen képességek és személyiségjellemzök szükségesek a hatékony munkavégzéshez a pedagóguspályán?

- Mit nyújtott a pedagógusképzés?

- Milyen módszerek lennének hatékonyak a felkészítés javításához?

\footnotetext{
${ }^{1}$ Az elővizsgálatban részt vett: Bernáth László, Gyebnár Viktória, Horváth Judit, Ivády Tímea, Solymosi Katalin, Soós István, Somogyi Mónika, Szegö Ágnes, Zétényi Ágnes. Köszönet továbbá Winter Viktóriának az adatfeldolgozásban nyújtott segítségért.
} 
A minta a pályán levő pedagógusból állt. A kérdőíves felmérést a 2006-2007es tanévben végeztük, az ELTE PPK pedagógus-szakvizsgás továbbképzésére járó hallgatók körében. Azért esett a választás erre a csoportra, mert a képzésre az ország minden részéből érkeznek hallgatók, és munkakörüket tekintve is széles körből tudtunk így információkat meríteni. A mintán belül nem szelektáltuk a résztvevők körét, az adott időszakban minden számunkra elérhető hallgatót megkerestünk, a kérdőív kitöltése önkéntes és anonim volt. Az adatfelvételt a tanulmány szerzője, valamint munkatársai végezték.

\section{A minta összetétele}

A vizsgálatban 241 pedagógus vett részt. A férfiak és nők aránya nagyon kiegyensúlyozatlan, az országos adatoknál is nagyobb a nők aránya, a minta $90 \%$-a nő, ami a PPK által hirdetett továbbképzési szakoknak köszönhető. A kínálatban felülreprezentáltak a pedagógiai és pszichológiai képzések, sok az óvópedagógus és tanító, akik túlnyomó többségükben nők, és nem szerepelnek a müszaki irányok, ahol a férfiak aránya nagy.

A minta életkori eloszlása és pedagógusi tapasztalatai

A kérdezettek életkori megoszlása és a pedagógiai tapasztalatok tekintetében egyaránt kiegyensúlyozott (1. táblázat)

1. táblázat: A pedagógusok életkori megoszlása

\begin{tabular}{|l|c|c|c|c|c|}
\hline & $\begin{array}{c}\text { Válaszolók } \\
\text { száma }\end{array}$ & Minimum & Maximum & Átlag & Szórás \\
\hline életkor & 239 & 24,0 & 60,0 & 41,410 & 7,2 \\
\hline mióta tanít & 235 & 2 & 31 & 17,54 & 7,4 \\
\hline
\end{tabular}

A válaszolók életkora 24 és 60 év közt található, átlagos életkoruk 41,4 év, a szórás 7,2 , a mintában egyaránt képviselve van mind a fiatal, mind az idős korosztály, ugyanakkor a középgeneráció, a 35 és 50 év közöttiek alkotják a többséget. A legkevesebb gyakorlattal bíró pedagógus is két éves tapasztalattal rendelkezik, a legrégebb óta tanító 30 éve van a pályán. Az tanított évek száma átlagosan 17,5 év, a szórás 7,4. A tanított évek szempontjából viszonylag egyenletes az eloszlás, a nagyon kevés és a nagyon sokévnyi tapasztalattal rendelkezők alulreprezentáltak. Ez következik az életkori összetételből is, egyedül a 25 éve tanítók aránya kiugró, ők teszik ki a minta 10,4\%-át.

Mind a kor szerinti, mind a pályán töltött idő szempontjából a minta összetétele a vizsgálat számára előnyös, mert a pályán már jelentős tapasztalattal rendelkező „középgeneráció” véleménye a leginkább tanulságos számunkra. 
A minta megoszlása megyék szakok, iskolatípus és munkakör szerint

A minta 42,7\%-a budapesti, jelentős arányú még a Pest megyében dolgozók aránya $(21,6 \%)$, de a további 16 megye is képviselt kisebb-nagyobb arányban. Az általunk rajzolt kép így ebböl a szempontból nem reprezentatív, hangsúlyosan a Budapest és Budapest környéki régiót képviseli, de jelentős mértékủ a vidéki régiók aránya is.

A válaszolók az óvónőktől a gimnáziumi tanárokig minden pedagógiai munkakört lefednek, a nem osztálykeretben tanító, fejlesztő pedagógusok és egyéb nem osztálytanító (pl. nevelőtanár) aránya $8,7 \%$, ami az iskolai alkalmazásuk arányához képest jelentős (2. táblázat).

2. táblázat: A válaszolók munkaköre

\begin{tabular}{|l|c|c|}
\hline & Válaszolók száma & $\%$ \\
\hline óvónő & 18 & 7,5 \\
\hline tanító & 42 & 17,4 \\
\hline tanár & 146 & 60,6 \\
\hline fejlesztő pedagógus & 14 & 5,8 \\
\hline egyéb, gyermekekkel dolgozó & 7 & 2,9 \\
\hline egyéb & 14 & 5,8 \\
\hline Total & 241 & 100,0 \\
\hline
\end{tabular}

A minta 60,6\%-a általános iskolai és középiskolai tanár. Az általános iskola és gimnázium aránya közel azonos, a pedagógusok 38,7\% dolgozik általános iskolában, 34\%-a gimnáziumban, illetve olyan iskolában, amelynek gimnáziumi tagozata is van. A gimnáziumokon belül is differenciált a minta, a 4 osztályos gimnáziumtól a 6 és 8 osztályos formán át a 12 évfolyamos iskoláig. Viszonylag kevés a szakközépiskolai pedagógus, és elenyésző számban szerepelnek a kérdezettek közt a szakiskolai oktatók.

A humán és reál szakok képviselete kiegyenlített (28,2, ill. 22,8\%), a készség tárgyat tanítók aránya az oktatott tárgyak arányának megfelel $(5,8 \%)$.

A mintában - ha eltérő arányban is - minden jellemző beosztás képviselve van. A kérdezettek 5,5\%-a vezető beosztású, igazgató vagy igazgató helyettes, 17,4\%-uk munkaközösség vezető. A többség beosztott pedagógus, 31,5\%-uk osztályfőnök, de legnagyobb $(41,3 \%)$ a speciális funkcióval nem rendelkezők aránya.

Összességében a mintára életkor, tanítási tapasztalat és oktatott szak tekintetében a kiegyensúlyozottság jellemző. A beosztás tekintetében a kérdezettek aránya az iskolai arányokat közelíti. Település tekintetében a minta ugyan országos merítésü, de többségében Budapest és Pest megye területéröl származik. 


\section{A pedagógusok véleménye a kérdöivek alapján}

Az általunk összeállított kérdőívet a melléklet tartalmazza. Az eredményeket a kérdőív négy kérdésköre alapján mutatjuk be:

- A pedagógus feladatok fontossága a válaszoló szerint, és a ráfordított tényleges munkaidő.

- Milyen tulajdonságok fontosak a pedagógus pályán, és mennyire fejlesztette azt a képzés?

- Mi segített a pályára felkészülésben?

- Mit várt és mit kapott a képzésben?

A pedagógusi feladatok fontossága a válaszoló szerint és a ráfordított tényleges munkaidő

A pályán jellemzően előforduló tevékenységi köröket ítéltettük meg a pedagógusokkal ötfokú skálán egyrészt fontosság szerint, másrészt abból a szempontból, hogy mennyire elégedettek a ténylegesen az adott feladatkörre fordított idővel. Az alapkérdés az volt, hogy a fontosságához mérten elegendő időt tudnak-e fordítani az egyes tevékenységekre, vagy úgy érzik, túlságosan is sok idejük telik el ezekkel a tevékenységekkel - tulajdonképpen más feladatok rovására.

Az 1. ábrán együtt ábrázoltuk ötfokú skálán a feladatok fontosságát, és az ezekre fordított idővel való elégedettséget. Az idő grafikonon „0” érték azt jelenti, hogy éppen elegendő idő áll rendelkezésre, a skála -2-től +2-ig terjed, a negatív érték az időhiányt, a pozitív azt jelzi, hogy túlságosan sok időt vesz el ez a feladat.

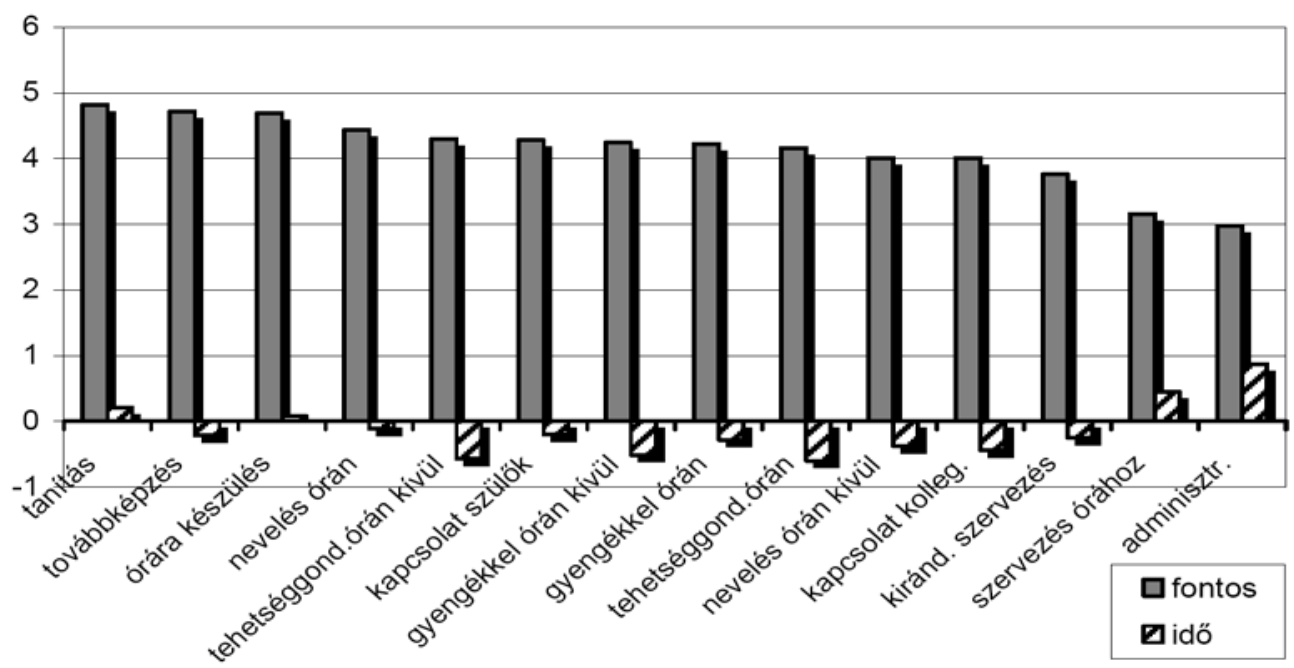

1. ábra: Pedagógusi feladatok és a ténylegesen ráfordított idő 
A pedagógusok a felkínált feladatkörök mindegyikét a pedagógusi feladatokhoz tartozónak ítélték, de a fontosságuk eltérő (Friedman $\mathrm{p}<0,001$ ). A másik két feladatkör a tanítás elsődlegességét mutatja. Több ponton találunk szignifikáns különbséget a feladatkörök fontosságának megítélésében, a fontosság lépcsőzetesen csökken, töréspontokat az órára készülés és nevelés órán (egy mintás t $p<0,001$ ), nevelés órán és tehetséggondozás órán kívül $(p<0,05)$, a tehetséggondozás órán és nevelésórán kívül (egy mintás $\mathrm{t} p<0,053$ ), a kapcsolat kollégákkal és kirándulásszervezés $(\mathrm{p}<0,001)$, szervezés órához kapcsolódóan $(\mathrm{p}<0,001)$ és adminisztráció $(\mathrm{p}<0,05)$ változók közt van. Az adminisztrációra, mint legkevésbé fontos tevékenységre is hármas értéket adtak az ötfokú skálán, „közepes mértékben” fontosnak érezték ezt a tevékenységet is.

A legfontosabb feladatnak a tanítást tartják és a ráfordított időt is elegendőnek, sőt néha az optimálisnál többnek is érzik. A tanításhoz szervesen tartozik az önképzés - továbbképzés és órákra készülés formájában - ezek fontossága megegyezik. A továbbképzésre járás fontosságának hangsúlyozása a speciális mintavételnek is tulajdonítható, mivel az éppen továbbképzésen ülöket kérdeztük. A következö feladatcsoport az átlagtól eltérőkkel (gyengék és tehetségesek) való foglalkozást, valamint ugyanilyen mértékben fontosnak érzik a szülőkkel való kapcsolattartást is. Ez azért fontos, mert mint látni fogjuk, a szülőkkel való kapcsolattartás kétarcú, a faktoranalízis alapján az átlagtól eltérőekkel való foglalkozás mellett, sőt ennél nagyobb mértékben a szervezés faktor része.

A pedagógusok általában úgy érzik, hogy az órákhoz kapcsolódó tevékenységekre elegendő időt tudnak fordítani (készülés, tanítás, - sőt szervezési munkát, amely az órákhoz kapcsolódóan szükséges, túlzottnak tartják). Az órai feladatok közül egyedül a tehetségesekkel való foglalkozás lehetőségeivel elégedetlenek, $63 \%$ tartja kevésnek, sőt 10,4\% úgy érzi, hogy egyáltalán nincs idő az órákon erre a feladatra.

Azok a feladatok, amelyekre kevés idő jut, túlnyomórészt órán kivüli tevékenységek, és jellemzően az átlagtól eltérő tanulókkal való foglalkozást jelentik: tehetségesekkel és gyengékkel való foglalkozást, és az órán kívüli nevelési feladatokat. Ez a tanárképzés számára fontos információ. Arra hívja fel a figyelmet, hogy fontos feladat a fejlődéspszichológiai és személyiségpszichológiai ismeretek, és tanulók megismerésének és a differenciálás módszereinek tanítása a pedagógusjelölteknek. Ahhoz, hogy képesek legyenek hatékonyabban kezelni az átlagtól eltérő tanulókat, a legkézenfekvőbb és leghatékonyabb mód véleményünk szerint a tanárok alaposabb felkészítése a problémák felismerésére és a differenciált módszerek alkalmazására.

Elgondolkodtató az is, hogy a kollégákkal való kapcsolattartást 47,5\% kevésnek tartja. Ez azért figyelemre méltó, mert az egyénre szabott módszerek megtalálásához az egyik potenciális segítség a kollegák véleménye, együttmüködése, szakmai segítsége lehetne. 
Túlzott időráfordításnak az adminisztratív feladatokat és az órák előkészítéséhez tartozó szervező munkáját tartják. Ez az a két terület, ahol a többség közepesen vagy ennél is kevésbé fontosnak érzi a feladatokat. A válaszolók közel harmada $(28,2 \%)$ kevéssé vagy egyáltalán nem tartja a pedagógus feladatának az adminisztrációt. Ugyanakkor a pedagógusi tevékenység szerves részének tekintik az órán kívüli foglalkozást a gyerekekkel. Az órán kívüli nevelést 36,6\%-uk elsőrendủen fontos feladatnak tartja, további 35,7\% gondolja „fontosnak” (kérdőívben 4-es érték).

Ennél is jelentősebb, $80 \%$ fölötti az átlagtól eltérő tanulókkal való foglalkozás fontosnak ítélése: a tehetségesekkel való foglakozást 46\%-uk elsőrendủen fontos feladatnak tartja, további $40,2 \%$ gondolja fontosnak, a gyengékkel való órán kívüli foglakozásra ugyanezek az értékek $46,6 \%$ és $36,4 \%$.

A feladatkörök tematikus egységekbe rendezhetőek. A válaszok faktoranalízise alapján öt faktor rajzolódik ki (3. táblázat).

3. táblázat: A feladatkörök faktoranalízise a fontosság alapján

\begin{tabular}{|l|c|c|c|c|c|}
\hline \multirow{2}{*}{} & \multicolumn{5}{|c|}{ Faktorok } \\
\cline { 2 - 6 } & 1 & 2 & 3 & 4 & 5 \\
\hline tanítás (fo) &, 280 &,- 273 & $3,778 \mathrm{E}-02$ & $1,545 \mathrm{E}-02$ & $\mathbf{6 9 8}$ \\
\hline órára készülés (fo) & $-1,313 \mathrm{E}-02$ &, 253 & $-5,796 \mathrm{E}-04$ & $8,250 \mathrm{E}-03$ & $\mathbf{8 0 2}$ \\
\hline nevelés órán (fo) &, 387 &,- 100 &, 247 & $\mathbf{6 5 7}$ & $-6,545 \mathrm{E}-02$ \\
\hline $\begin{array}{l}\text { nevelés órán kívül } \\
\text { (fo) }\end{array}$ & $-3,984 \mathrm{E}-02$ &, 243 & $3,218 \mathrm{E}-02$ & $\mathbf{, 8 4 7}$ & $9,210 \mathrm{E}-02$ \\
\hline kapcsolat kolleg. (fo) & $\mathbf{3 5 2}$ &, 207 & $\mathbf{, 4 6 0}$ &, 153 & $7,314 \mathrm{E}-02$ \\
\hline adminisztr. (fo) &,- 142 & $-2,830 \mathrm{E}-02$ & $\mathbf{, 6 0 6}$ &, 196 &, 495 \\
\hline $\begin{array}{l}\text { tehetséggond. órán } \\
\text { (fo) }\end{array}$ & $\mathbf{7 9 2}$ &, 203 & $8,067 \mathrm{E}-02$ & $-3,041 \mathrm{E}-02$ & $9,277 \mathrm{E}-02$ \\
\hline $\begin{array}{l}\text { tehetséggond. órán } \\
\text { kívül (fo) }\end{array}$ &, 326 & $\mathbf{, 6 5 8}$ & $2,891 \mathrm{E}-02$ &, 193 & $-5,899 \mathrm{E}-02$ \\
\hline gyengékkel órán (fo) & $\mathbf{, 8 0 4}$ &, 170 & $3,225 \mathrm{E}-02$ &, 188 & $6,199 \mathrm{E}-02$ \\
\hline $\begin{array}{l}\text { gyengékkel órán kívül } \\
\text { (fo) }\end{array}$ &, 290 & $\mathbf{, 6 1 6}$ &,- 133 &, 495 & $8,045 \mathrm{E}-02$ \\
\hline kiránd. szervezés (fo) & $9,129 \mathrm{E}-02$ & $\mathbf{5 3 9}$ &, 200 & $9,367 \mathrm{E}-02$ & $-8,084 \mathrm{E}-02$ \\
\hline szervezés órához (fo) & $3,441 \mathrm{E}-02$ &, 172 & $\mathbf{, 7 8 8}$ & $-6,530 \mathrm{E}-02$ & $-7,018 \mathrm{E}-02$ \\
\hline kapcsolat szülök (fo) & $\mathbf{, 4 2 5}$ &, 213 & $\mathbf{4 9 0}$ &, 231 & $2,686 \mathrm{E}-02$ \\
\hline továbbképzés (fo) & $5,180 \mathrm{E}-02$ & $\mathbf{, 6 2 7}$ &, 249 &,- 102 &, 173 \\
\hline
\end{tabular}

Rotated Component Matrix Extraction Method: Varimax 
A faktoranalízis alapján meghatározott öt faktor:

1. átlagtól eltérőkkel való foglalkozás (tehetségesek és gyengék),

2. órán kívüli foglalkozás (tehetségesekkel, gyengékkel, kirándulás szervezése és továbbképzésre járás),

3. szervezés és kapcsolattartás,

4. nevelés órán és órán kívül,

5. tanítás.

A feladatkörök faktorokba rendeződése a várakozásainknak megfelelően alakult. A tanítás, a nevelés, a gyerekekkel való órán kívüli foglalkozás, az átlagtól eltérő tanulók problémáinak kezelése és a szervezés, mint elkülönülő feladatok öt faktorként válnak külön a pedagógusok szerint is. A faktorokhoz tartozó kérdések azonban néhol figyelemre méltó tanulságokat rejtenek.

A szülőkkel és a kollégákkal való kapcsolattartás elsősorban az adminisztratív feladatkörhöz sorolódik. Van ugyan némi együttjárás a szülőkkel való kapcsolattartás és az átlagtól eltérö tanulókkal való foglalkozás közt, és ennél gyengébb, de létező korreláció van a kollégákkal való kapcsolat és az átlagtól eltérö tanulókkal való foglalkozás közt is. A faktorba sorolásnál mégis dominánsan az a kép rajzolódik elénk, hogy mind a szülőkkel, mind a kollégákkal való kapcsolatot sokkal inkább érzik az adminisztratív feladatokkal egy kategóriába tartozónak, mint olyannak, amely a gyerekek problémáit hivatott megoldani. Különösen elgondolkodtató, hogy a nevelés faktorban csupán a gyengékkel való órán kívüli foglalkozás jelenik meg, mint ami elsősorban a neveléssel kapcsolatos, de se a szülőkkel, se a kollegákkal való kapcsolattartás nem tartozik ide. Azt láthatjuk, hogy a nevelés „magánügy”, a pedagógusok amennyiben fontosnak érzik, egyedül küzdenek ezzel a feladattal.

Milyen tulajdonságok fontosak a pályán, és mennyire fejlesztette ezeket a képzés?

A pályán fontos tulajdonságok listája nagyon széles körü lehetne, ezért az itt vizsgált szempontokat az előzetes interjúk alapján az interjúkat készítő pszichológusok segítségével határoztuk meg. Az interjúban arra kérdeztünk rá, hogy milyen tulajdonságok szükségesek a pálya gyakorlásához, és milyen egyéniségek a legalkalmasabbak a pályára. A vélemények némileg megoszlottak, ezért célszerủnek tartottuk megítéltetni a tulajdonságok fontosságát is.

A második szempont az volt, hogy mennyire hisznek a tulajdonságok fejleszthetöségében - ez egyszersmind az implicit pszichológiai nézeteikről is információt ad számunkra.

A harmadik szempont a saját képzése hatékonyságának megítélését mérte föl (2. ábra). 


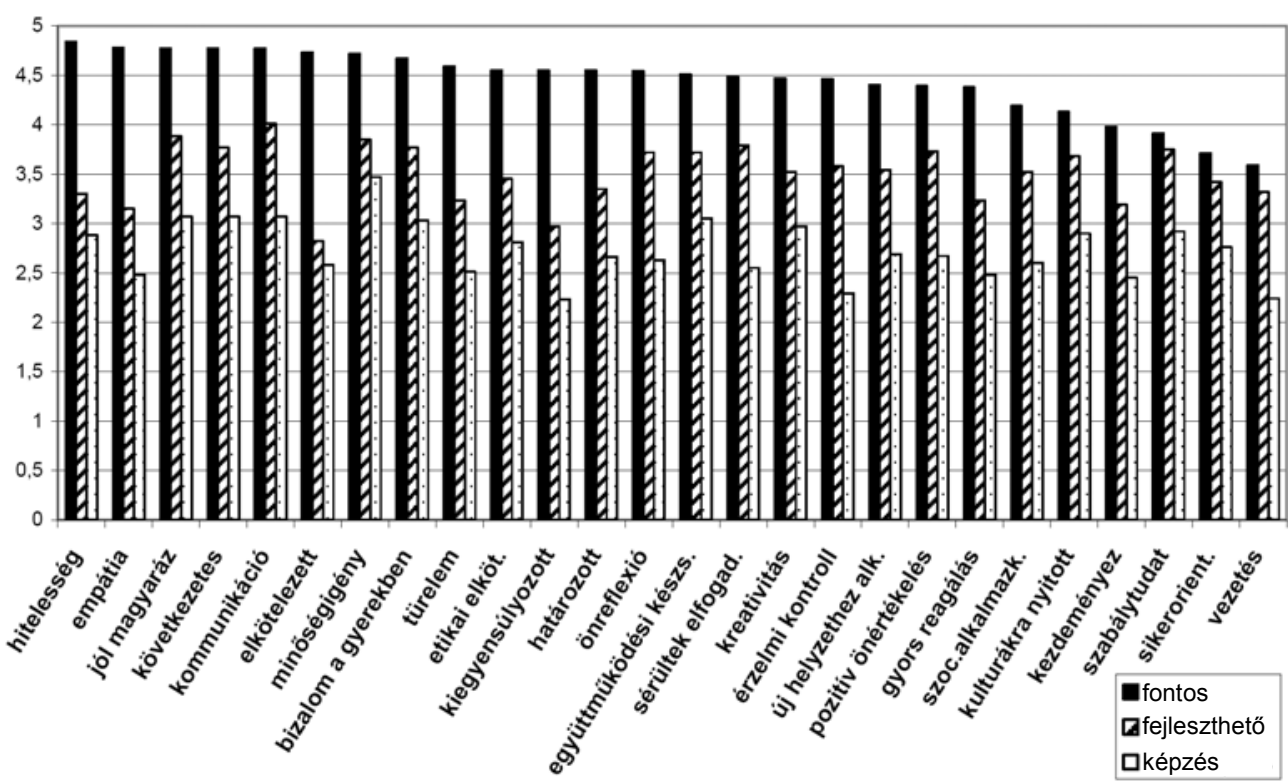

2. ábra: Tulajdonságok fontossága és fejlesztése

A kínált tulajdonságlista szinte minden elemét fontosnak, vagy akár nélkülözhetetlennek tartják a pedagógusok. Az értékek a kezdeményezőkészség, szabálytudat, sikerorientáltság és a vezetés képessége kivételével négy feletti értékủek, vagyis fontosak. Mégsem homogén a tulajdonságok fontosságának megítélése, öt alcsoport különíthető el (Friedman próba $\mathrm{p}<0,001)$. A gyermekekbe vetett bizalom és türelem (egymintás $t \mathrm{p}<0,05)$; a gyors reagálás és szociális alkalmazkodás $(\mathrm{p}<0,001)$; kultúrára való nyitottság és kezdeményező készség $(\mathrm{p}<0,001)$; a szabálytudat és sikerorientáltság tulajdonságok közt van szignifikáns $(\mathrm{p}<0,001)$ csökkenés.

A kevésbé fontos tulajdonságokat átlagos mértékben tartják fejleszthetőnek, és viszonylag elégedettebbek ezek fejlesztésével.

A képzéssel összességében nem lehetünk elégedettek, minden tulajdonság esetén azt láthatjuk, hogy a képzés kevesebbet nyújtott, mint amennyit a pedagógusok szerint kellene, és éppen a fontosnak ítélt tulajdonságok esetén nagyobb az elégedetlenségük.

A pedagógusok véleménye szerint a legkevésbé fejleszthető tulajdonságok: az elkötelezettség, kiegyensúlyozottság, empátia, kezdeményező készség, türelem, gyors reagáló készség és a hitelesség (3,3 alatti értékek). A 26 vizsgált tulajdonság közt, az előbb említettek közül a hitelesség, empátia és az elkötelezettség a legfontosabbnak tartott csoportban található, és a türelem is a második blokk első tagja.

A hitelesség és az empátia - a feltétel nélküli elfogadás mellett - azok az alapvető tulajdonságok, amelyeket a humanisztikus pszichológia az egészséges szemé- 
lyiségfejlődés alapfeltételeinek tart. Ilyen értelemben a pedagógusok nézetei korszerü pszichológiai szemléletet mutatnak, amikor ezeket a fontossági sorrend élére sorolják, ugyanakkor ezek a tulajdonságok az önismeret és mások megismerése révén fejleszthetők. Ha ehhez hozzátesszük az előzőekben vizsgált feladatstruktúrát, amelyben a nevelés és az átlagtól eltérőekkel való foglalkozás is fontos szerepet kap, akkor kijelenthetjük, hogy a pedagógusképzés számára is megkerülhetetlen feladat ezek fejlesztése.

Valóban fontos kérdés azonban, hogy ezeket a tulajdonságokat milyen eszközökkel és módszerekkel lehet hatékonyan fejleszteni. A választ csak a különböző módszerek szisztematikus hatásvizsgálatával lehetne megadni, azonban a jelen vizsgálat következő kérdése is nyújt számunkra néhány támpontot, mivel a harmadik kérdésben az vizsgáljuk, mi segítette a pályához szükséges tulajdonságok alakulását.

A fejleszthetőség kérdésében érdemes az elkötelezettséget közelebbről megvizsgálni, egyrészt azért, mert ezt tartják a pedagógusok legkevésbé fejleszthetőnek, másrészt azért, mert ez nem ,igazi tulajdonság”, hanem attitüd, a pályához való hozzáállás.

Ahhoz, hogy az elkötelezettségben szerepet játszó képzési elemekröl és egyéb hatásokról információt szerezzünk, a második kérdésben szereplő válaszokat: t. i., hogy az elkötelezettség kialakulásában a tanárképzés milyen mértékben volt hatékony, korreláltattuk a 3. kérdésre adott értékekkel. Az elkötelezettség nyilvánvalóan nagyon sok tényezőtől függ, ezért magas korrelációs értékeket nem vártunk.

Az attitüdformálásban az indirekt hatások szerepe köztudottan jelentős, így a példanyújtás várhatóan az egyik hatékony eszköz. A főiskolai/egyetemi tanár modellek hatásával korrelációt találunk $(\mathrm{r}=0,202 \mathrm{p}<0,01)$. Nem ez az egyetlen faktor azonban, amellyel szignifikáns kapcsolatot találunk. Ilyen tényező még a helyzetgyakorlatok $(\mathrm{r}=0,283)$, hospitálás, $(\mathrm{r}=0,235)$, tanítási gyakorlat $(\mathrm{r}=0,207)$, interjúkészítés $(\mathrm{r}=0,334)$, esettanulmány $(\mathrm{r}=0,184)$, pszichológia előadás $(\mathrm{r}=0,303)$, pedagógia előadás $(\mathrm{r}=0,394)$, szemináriumok $(\mathrm{r}=0,327)$, tréning $(\mathrm{r}=0,164)$. A pályán szerzett tapasztalatok: pedagógiai tapasztalatok $(\mathrm{r}=0,142)$, kollégák segítsége $(\mathrm{r}=0,155)$ és a tanártovábbképzés $(\mathrm{r}=0,361)$ szintén összefüggést mutat az elkötelezettséggel, ez utóbbi már lehet, hogy inkább okozata, mint oka az elköteleződésnek.

Magukból a korrelációs értékekből nem lenne érdemes messzemenő következtetéseket levonni, mivel nem csupán a továbbképzésnél vetódik fel az a szempont, hogy az elkötelezettség hozzájárul a továbbképzési lehetőségek kihasználásához, hanem a képzés elemeinél is müködhet a hatás visszafelé, elképzelhető, hogy az elkötelezettebbek nagyobb energiát fektetve a feladatok elvégzésébe többet is profitálnak.

A fontos tanulság számunkra a korrelációk alapján az, hogy az elkötelezettség is fejleszthető, mivel ez a hozzáállás, a mikrotanítást kivéve, a tanárképzés összes elemével korrelál, ugyanakkor független a családi és iskolán kívüli tapasztalatoktól. 
Visszatérve a tulajdonságok elemzéséhez a 3. ábrán azt mutatjuk be, hogy a fontosságához képest a képzés mennyire segítette elő az egyes tulajdonságok fejlődését.

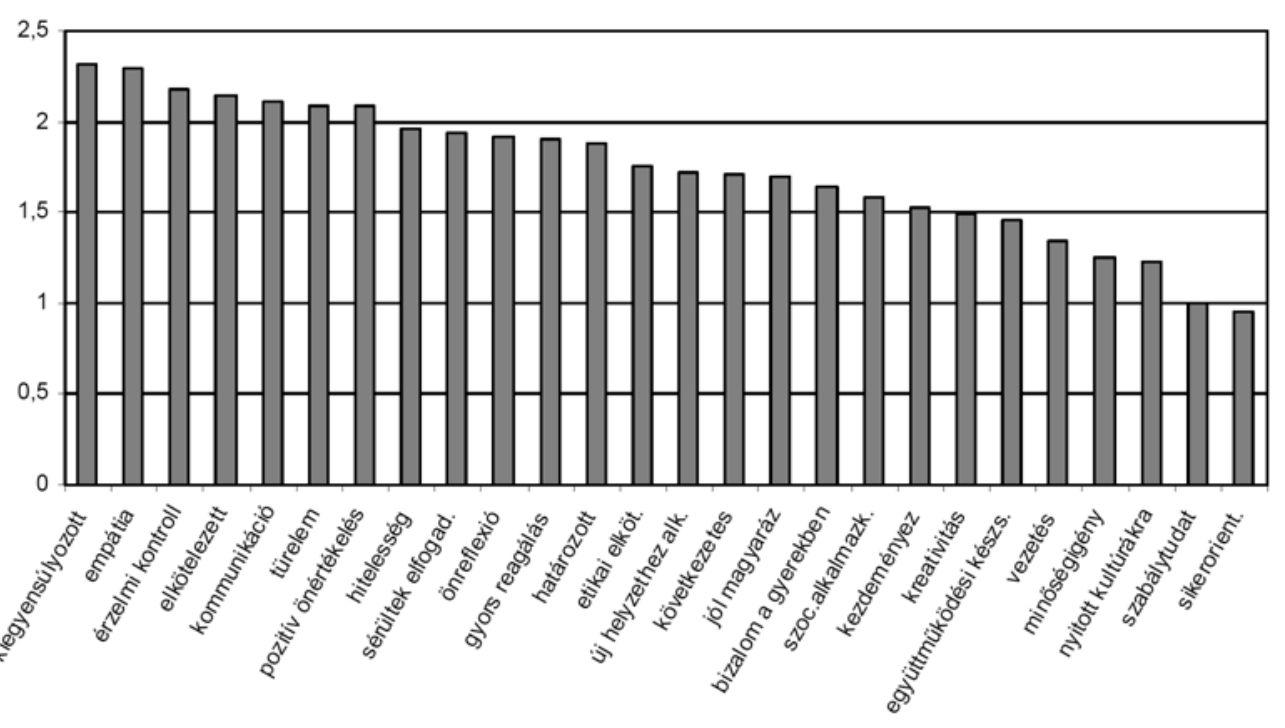

3. ábra: Mekkora a pedagógusképzés hiányossága a tulajdonság fontosságához képest (fo-tk)

A tulajdonságok fejlesztésével különböző mértékben fogalmaznak meg elégedetlenséget a válaszolók (Friedman $\mathrm{p}<0,001$ ). A tulajdonságok viszonylag egyenletes mértékben csökkenő sort alkotnak, az egymás utáni tulajdonságok közt sehol nincs szignifikáns csökkenés, de a tulajdonságcsoportok közt már jelentös különbség van. A pedagógusok legkevésbé elégedettek azon tulajdonságok fejlesztésével, amelyek a személyes kiegyensúlyozottság és a másokkal való hatékony, kompetens bánásmód körébe tartoznak (kiegyensúlyozottság, empátia, érzelmi kontroll, elkötelezettség és kommunikációs készség).

Úgy is fogalmazhatunk, hogy az oktatás megszervezésére, a tanulás kereteinek biztosítására viszonylag felkészültnek érezték magukat (vezetés, minőségigény, szabálytudat). Az oktatással kapcsolatos tulajdonságok tekintetében (jól magyaráz, következetes) közepes az elégedettségük, ami feltehetően a képzésnek köszönhetö. A hiányosságok tehát föként a személyes alkalmasságuk és a gyerekekkel való bánni tudás területén vannak.

Érdemes kiemelni három tulajdonságot, amelyekkel kapcsolatban viszonylag elégedetten nyilatkoznak a pedagógusok a saját képzésükről: a minőségigény, szabálytudat és a kultúrákra való nyitottság. Ezeket tekinthetjük a képzés erősségeinek, ezekkel kapcsolatban a többihez viszonyítva sokat kaptak a hallgatók. A mi- 
nőségigény kifejezetten fontosnak tartott tulajdonság (átlag 4,72), és a képzés ebben nyújtott a legtöbbet (átlag 3,47), de a másik két tulajdonság esetén is igaz, hogy abszolút értékben is a többi tulajdonsághoz viszonyítva hatékonyan fejlesztette a képzés. A sikerorientáltság fejlesztéséről nyilatkoznak legelégedettebben, azonban ezzel kapcsolatban egy kicsit összetettebb a kép. Itt a relatív elégedettség annak köszönhető, hogy a képzés csak közepes mértékben nyújtotta, de fontosnak is közepes mértékben tartják.

Mi segített a pályára felkészülésben?

A vizsgált szempontokat ez esetben is az interjúkban a pedagógusok által fontosnak ítélt hatások listájából állítottuk össze, kiegészítve az általunk a gyakorlatban kipróbált, általánosan alkalmazott, vagy a hallgatóknak fakultatív formában nyújtott képzési elemekkel.

A válaszok alapján faktoranalízist végeztünk. (A faktoranalízishez további, rendelkezésünkre álló, diákoktól származó kérdőiveket is felhasználtunk.) A számítások alapján hat faktor rajzolódik ki. (4. táblázat).

4. táblázat: A pedagógusi képességek kialakulásában szerepet játszó faktorok

\begin{tabular}{|l|c|c|c|c|c|c|}
\hline & 1 & 2 & 3 & 4 & 5 & 6 \\
\hline $\begin{array}{l}\text { családi } \\
\text { nevelés }\end{array}$ &, 132 &, 462 & $\mathbf{, 6 7 1}$ &, 198 & $4,738 \mathrm{E}-02$ &,- 110 \\
\hline adottság &,- 105 &,- 143 & $\mathbf{, 7 5 2}$ &,- 220 &,- 281 &, 352 \\
\hline ped. példa & $-4,331 \mathrm{E}-02$ &, 353 &,- 291 &,- 229 & $\mathbf{4 8 2}$ &, 406 \\
\hline $\begin{array}{l}\text { gyakorlati } \\
\text { tapasztalat }\end{array}$ & $8,740 \mathrm{E}-02$ & $\mathbf{, 7 7 6}$ & $2,349 \mathrm{E}-02$ &,- 135 &, 179 &, 224 \\
\hline $\begin{array}{l}\text { helyzet- } \\
\text { gyakorlat }\end{array}$ &, 240 &, 318 &,- 196 & $\mathbf{, 6 1 1}$ &, 102 &, 389 \\
\hline hospitálás & $5,970 \mathrm{E}-02$ & $\mathbf{6 6 6 0}$ & $1,032 \mathrm{E}-02$ &, 299 &, 169 &, 175 \\
\hline $\begin{array}{l}\text { tanítási } \\
\text { gyakorlat }\end{array}$ &,- 132 & $4,973 \mathrm{E}-02$ &, 183 &, 457 &, 173 &, $\mathbf{6 5 0}$ \\
\hline mikrotanítás &, 260 &, 135 & $-2,631 \mathrm{E}-02$ & $9,856 \mathrm{E}-02$ & $8,270 \mathrm{E}-02$ &, $\mathbf{7 8 5}$ \\
\hline interjúk & $\mathbf{, 5 7 3}$ &, 113 &, 165 &, 269 &, 208 &, 155 \\
\hline $\begin{array}{l}\text { eset- } \\
\text { tanulmány }\end{array}$ & $\mathbf{5 4 9}$ &, 326 &,- 114 &, 177 &, 412 &, 122 \\
\hline $\begin{array}{l}\text { pszichológia } \\
\text { előadás }\end{array}$ & $\mathbf{, 8 4 0}$ & $9,516 \mathrm{E}-03$ &,- 154 &, 224 & $-1,537 \mathrm{E}-02$ & $-4,164 \mathrm{E}-03$ \\
\hline
\end{tabular}




\begin{tabular}{|l|c|c|c|c|c|c|}
\hline & 1 & 2 & 3 & 4 & 5 & 6 \\
\hline $\begin{array}{l}\text { pedagógia } \\
\text { elöadás }\end{array}$ & $\mathbf{8 8 0}$ &, 294 & $2,344 \mathrm{E}-02$ & $5,414 \mathrm{E}-04$ &, 171 &,- 129 \\
\hline szeminárium & $\mathbf{7 9 8}$ & $8,807 \mathrm{E}-03$ &, 306 & $1,195 \mathrm{E}-02$ & $7,776 \mathrm{E}-02$ &, 375 \\
\hline tréning &, 146 & $5,550 \mathrm{E}-02$ &, 114 & $9,963 \mathrm{E}-02$ & $\mathbf{, 8 3 6}$ & $-3,216 \mathrm{E}-02$ \\
\hline $\begin{array}{l}\text { pedagógus } \\
\text { modellek }\end{array}$ &, 281 & $3,644 \mathrm{E}-02$ & $-8,971 \mathrm{E}-02$ &,- 172 & $\mathbf{, 6 8 3}$ &, 360 \\
\hline $\begin{array}{l}\text { pedagógiai } \\
\text { tapasztalatok }\end{array}$ & $9,108 \mathrm{E}-02$ &, 177 & $-7,699 \mathrm{E}-02$ & $\mathbf{, 7 0 3}$ &,- 230 & $4,945 \mathrm{E}-02$ \\
\hline $\begin{array}{l}\text { kollégák } \\
\text { segítsége }\end{array}$ &, 192 &, $\mathbf{6 1 1}$ &,- 110 &, 125 &,- 122 &,- 103 \\
\hline $\begin{array}{l}\text { tovább- } \\
\text { képzés }\end{array}$ &, 338 & $-9,981 \mathrm{E}-02$ &, 244 & $\mathbf{, 6 9 9}$ &, 154 & $3,169 \mathrm{E}-02$ \\
\hline $\begin{array}{l}\text { egyéb } \\
\text { segítség }\end{array}$ & $7,500 \mathrm{E}-02$ &,- 149 & $\mathbf{8 2 8}$ & $4,288 \mathrm{E}-02$ &, 109 & $-7,092 \mathrm{E}-02$ \\
\hline
\end{tabular}

Extraction Method: Principal Component Analysis; Rotation Method: Varimax with Kaiser Normalization; a Rotation converged in 10 iterations.

A kapott 6 faktor a variancia 70,36\%-át magyarázza:

1. elmélet és gyakorlat a képzésben:

interjúk, esettanulmány, pszichológia előadás, pedagógia előadás, szeminárium,

2. közvetett tapasztalatok, mások tapasztalataiból tanulás:

gyakorlati (nem iskolai) tapasztalat gyermekekkel, hospitálás, kollégák segítsége,

3. „hozott értékek":

családi nevelés, adottság, egyéb segítség

4. saját pedagógiai tapasztalatok:

pedagógiai tapasztalatok, helyzetgyakorlat, tanártovábbképzés

5. tréning elemek a képzés során:

tréning, saját pedagógusok példája az iskolában és a képzés során

6. tanítási gyakorlatok:

tanítási gyakorlat a képzés során, mikrotanítás

Az első faktorba azok a „hagyományos” képzési elemek tartoznak, amelyeket a képző intézmény falain belül nyújt a pedagógusképzés, az előadások, szemináriumok és az ezekhez kapcsolódó feladatok. Ezektől elkülönülő faktorokban találjuk a hangsúlyozottan saját élményt nyújtó formát, a tréninget, ez az 5 . faktorban található. Figyelemre méltó tanulság, hogy a tréning és a pedagógus példák kerülnek 
egy faktorba, hasonló hatást fejtenek ki a maradandó élményt nyújtó pedagógus egyéniségek, mint a célzott képességfejlesztő tréningek.

A másik viszonylag új és saját élményre építő elem a képzésben, a mikrotanítás a 6. faktort alkotja a tanítási gyakorlattal együtt. Vagyis a mikrotanítás, amely a tanítási helyzetet szimulálja, az elvárásainknak megfelelően valóban hasonló tanulságokat jelent, mint maga a tanítási gyakorlat.

A második faktor olyan tapasztalatokat tartalmaz, amelyek valódi gyakorlati tapasztalatok, de bizonyos szempontból áttételesek. Egyrészt saját tapasztalatok, de nem iskolában szerezték azokat, másrészt kollégák tapasztalatainak átvétele, hospitálás vagy direkt segítség formájában.

A harmadik faktor olyan elemeket tartalmaz, amelyeket nem a képzés nyújt. Meglévő adottságok, családi szocializáció nyújtotta képességek, tapasztalatok, és ide sorolódik az „egyéb” kategória is. Az „egyéb” kategóriában a válaszolók 37,8\%-a ad csak választ. A többség nem jelezte, mi ez az „egyéb” hatás. Akik szövegesen is válaszoltak, a saját gyerekkel kapcsolatos élményeket, szakirodalmat és müvészeti alkotásokat említenek, illetve a válaszok jelentős része visszasorolható lenne az általunk megadott kategóriákba (iskolai és iskolán kívüli pedagógiai tapasztalatok, továbbképzések).

A negyedik faktor a saját pedagógiai tapasztalatokat tartalmazza. A helyzetgyakorlat és a továbbképzés együttjárása a pedagógiai tapasztalatokkal azt jelezheti, hogy ez utóbbiak a pedagógiai tapasztalatokhoz hasonlóan hasznosíthatóak a pedagógusok számára.

A vizsgált szempontok nem csupán a faktorok mentén függnek össze. A különböző faktorokba tartozó elemek közt is jelentős korrelációkat találunk, ami azt jelzi, hogy a képzési elemek nem függetlenek, kölcsönösen kiegészíthetik egymást, s akár növelhetik is egymás hatékonyságát.

Az egyes tapasztalatok együttjárása tanulságos ugyan, de ennél is fontosabb kérdés a pályára felkészülést biztosító élményekkel és tanulmányokkal kapcsolatban az ezekkel való elégedettség mértéke. Itt is ötfokú skálán ítéltettük meg, hogy mennyire segítettek az egyes tényezők. A 4. ábrán a hatékonyság sorrendjében ábrázoltuk a mért szempontokat.

A skála értékei: $1=$ egyáltalán nem segített; $2=$ kevéssé segített; $3=$ =közepesen; 4=nagymértékben; 5=teljes mértékben ez segített. Vagyis a kritérium elég szigorú, a négyes érték már meglehetős elégedettséget feltételez.

Az értékek viszonylag magas övezetben helyezkednek el, a legjelentősebb faktor a saját pedagógiai tapasztalat, aminek értéke átlagosan 4,55, legkevesebb haszna a szemináriumoknak van, de ennek átlag értéke is meghaladja a közepes szintet (átlag: 3,14 szórás: 1,13). Összességében azt mondhatjuk, hogy a válaszokból a kompetencia alakítás szempontjából, viszonylag pozitív kép rajzolódik ki. 


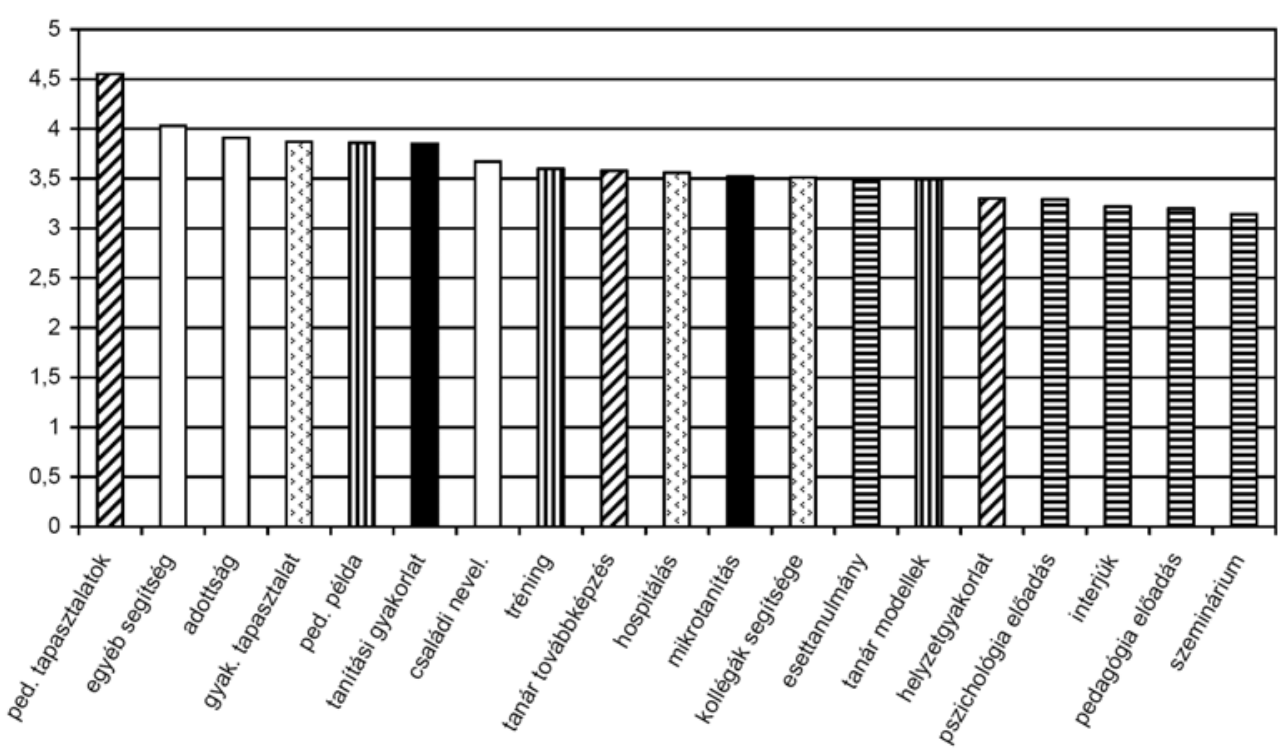

4. ábra: Mi segített a pedagógusi pályán?

A leghasznosabbnak a pedagógusok a saját tapasztalatából tanulást tartják (4. faktor). Ehhez a faktorhoz tartozik még a továbbképzés és a helyzetgyakorlatok, mindkettő gyakorlatorientált, saját élményeket nyújtó, vagy legalábbis saját élményekre építő forma. Ez aláhúzza a bolognai képzésben az MA képzés ötödik félévében tervezett féléves iskolai gyakorlat indokoltságát. Itt a képzés záró félévében, mentor által támogatottan, de éles pedagógiai helyzetben szerezhetnek majd tapasztalatokat a tanárjelöltek. Ennek külön előnye, hogy átlagos iskolai körülmények között fognak pedagógiai munkát végezni, ami a problémás, átlagtól eltérő tanulókkal kapcsolatos tapasztalatokat is jelenti.

A 4. ábrán a jelentős tényezők közt szerepelnek a ,hozott értékek” (3. faktor). Az adottságokra és a családi neveléssel kapott értékekre a képzés csak egy módon lehetne befolyással, a belépés szintjén, vagyis, hogy a pedagógus pályára jelentkezők közül az eleve rátermettebbeket választjuk ki. Ez az alkalmasság bonyolult és sokat vitatott kérdésköréhez vezetne, amely meghaladja az itt vizsgáltakat. Ez a kérdés egyébként a kérdöívekben a nyitott kérdése adott válaszokban is gyakran felvetetődik.

A pedagógusokkal kapcsolatos, még a képzés előtt szerzett tapasztalatok (az 5. faktorhoz tartozó „pedagógusok jó példája”) szintén hozott élmények, amelyekkel, mint a pályaszocializáció fontos elemeivel számolnunk lehet és kell is a képzés során. A képzés folyamán ezzel kapcsolatban a hozott élmények reflektív feldolgozása kívánatos. Ezt célozza a 2006-ban az ELTE BA/Bsc képzésében a tanári elökészítő modul részeként bevezetett „Pedagógiai tapasztalatok és nézetek” c. kurzus. 
Az 5. faktor három elemből áll, az említett pedagógusokkal kapcsolatos élményeken túl a tréningtapasztalatok és a képzésben résztvevő tanárok példája tartozik ide. A tanárképzés hatékonysága szempontjából fontos eszerint a képzés során nyújtott tanári példa és az alkalmazott oktatási gyakorlat. Itt a tanár-diák viszony és a tréning szerepe jár együtt, ami azért figyelemre méltó, mert ez az a képzési forma, ahol a diákok közötti kapcsolat leginkább kiépül, tapasztalataink szerint magas csoportkohézió alakul ki. A képzésben érdemes lenne hangsúlyt fektetni arra, hogy a hallgatók közt mód legyen a baráti kapcsolatok kialakulására , a tényleges társas támogató csoportban tanulásra, módszertani változatosságra a páros és csoportmunkák alkalmazása révén is. Nagyon fontos, hogy milyen az az oktatási közeg, amely a hallgatót a képzés során körülveszi. Ez tükrözödik a pedagógusok azon véleményében is, hogy a pedagógusképzés során őket tanítók, mint „tanár modellek” jelentős szerepéről (átlag 3,49; szórás 1,22) számolnak be. Érdemes ennek súlyát mérlegelve azt megfigyelni az ábrán, hogy a tanárok modell szerepe a legtöbb, az egyetem/föiskola falain belül nyújtott képzés hatását megelözi.

A tényleges iskolai tapasztalatok szerepe a tanárképzésben eszerint a felmérés szerint is elvitathatatlan. A tanítási gyakorlat (6. faktor), mint a pályára való felkészülés leglényegesebb eleme, a már végzés után szerzett iskolai tanítási tapasztalatok után a legfontosabb tanulási élmény. A tanítási gyakorlat jelentősége köztudott, ezt támasztják alá a hallgatói és vezetőtanári visszajelzések és tréningcsoportvezető tanárok tapasztalatai is.

Ezeknek a tapasztalatoknak a jelentőségét közelíti meg a tréning hatása, ami megelőzi még a hospitálás jelentőségét is.

Érdekes eredmény, hogy az előadások értékelése megelőzi a szemináriumokét. Ennek értelmezéséhez érdemes elöre tekintenünk a következőkben tárgyalt szempontra, hogy mennyire elégedettek a megkérdezettek a saját képzésük hatékonyságával. A 6. ábrán láthatjuk majd, hogy egyrészt fontosnak érzik a képzés nyújtotta elméleti tudást, másrészt meglehetősen elégedettek az elméleti felkészítéssel, különösen, ha a többi képzési cél megvalósulásának mértékével hasonlítjuk össze (lásd 7. ábra).

Az elméleti képzés hatékonyságával elégedettek lehetünk ezek alapján, sőt megkockáztatjuk, hogy ez az eredmény arra is utal, hogy a hallgatók tisztában vannak azzal, miért tanulnak „elméletben” pedagógiát és pszichológiát. Az elméleti tudás hasznával kapcsolatos tudatosság meglétét találtuk egy a saját hallgatóinkkal végzett vizsgálatban, ahol nyílt kérdésre adott a szöveges válaszaikban arról számoltak be, hogy a tanítási gyakorlaton ráismernek az elméletben tanultakra, néhányan maguktól is kiemelték, hogy hasznosítani tudták az elméletben tanultakat a tanítási gyakorlatuk során.

A képzés gyakorlati elemei közül két képzési formát érdemes kiemelni, mint amelyeknek a hatékonysága a legnagyobb - a tréninget és a mikrotanítást. Ez két olyan módszer, amelynek alkalmazása még nem teljesen általános. A tapasztala- 
tokkal rendelkezők \%-a itt a legkisebb, a mikrotanítással a válaszolók 66\%-ának, a tréningekkel kapcsolatban 68\%-nak volt tapasztalata. Az 5. ábrán azt is láthatjuk, hogy a hallgatók túlnyomó többsége nagymértékben (4), vagy teljes mértékben hasznosnak ítélte ezeket a foglakozásokat.

A gyakorlati képzési elemek közül még három olyat találunk, ahol jelentős a tapasztalatok hiányának jelzése. Kb. $15 \%$ számol be arról, hogy nem volt része helyzetgyakorlatban, esettanulmány készítésben, vagy meglepő módon szemináriumban sem.

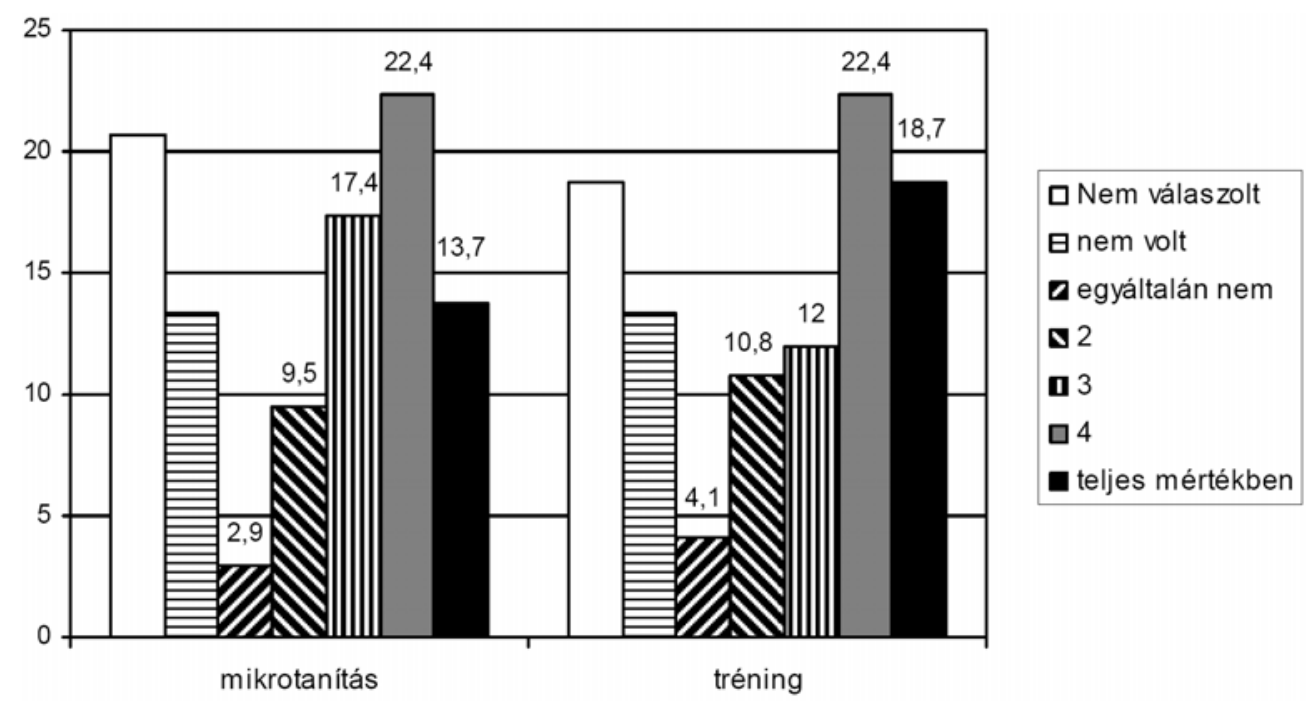

5. ábra: A mikrotanítás és a tréning hatékonyságának megítélése (a gyakoriság \%-a)

Mit várt és mit kapott a képzésben?

Az utolsó kérdésben azt vizsgáltuk, hogy az egyes feladatokra mennyire érezték felkészültnek magukat, valamint mennyire várnák el, hogy a képzés biztosítsa a felkészülésüket. Azért tartjuk lényegesnek, hogy a képzés hatékonyságát az elvárásokkal vessük össze, mert nem lenne szerencsés egy abszolút mértékhez („,ökéletes") mérni a hatékonyságot. Véleményünk szerint nem kérhető ugyanis számon egy képző intézménytől sem, hogy tökéletesen felkészült hallgatókat bocsásson ki. $\mathrm{Az}$ azonban tanulságos, hogy az elvárások és a tényleges felkészítés közt milyen területeken látnak nagy különbséget a pedagógusok, mert ezeken a területeken érdemes a képzést erösíteni.

A képzés nyújtott, és elvárt szintjét a 6. ábrán láthatjuk. 


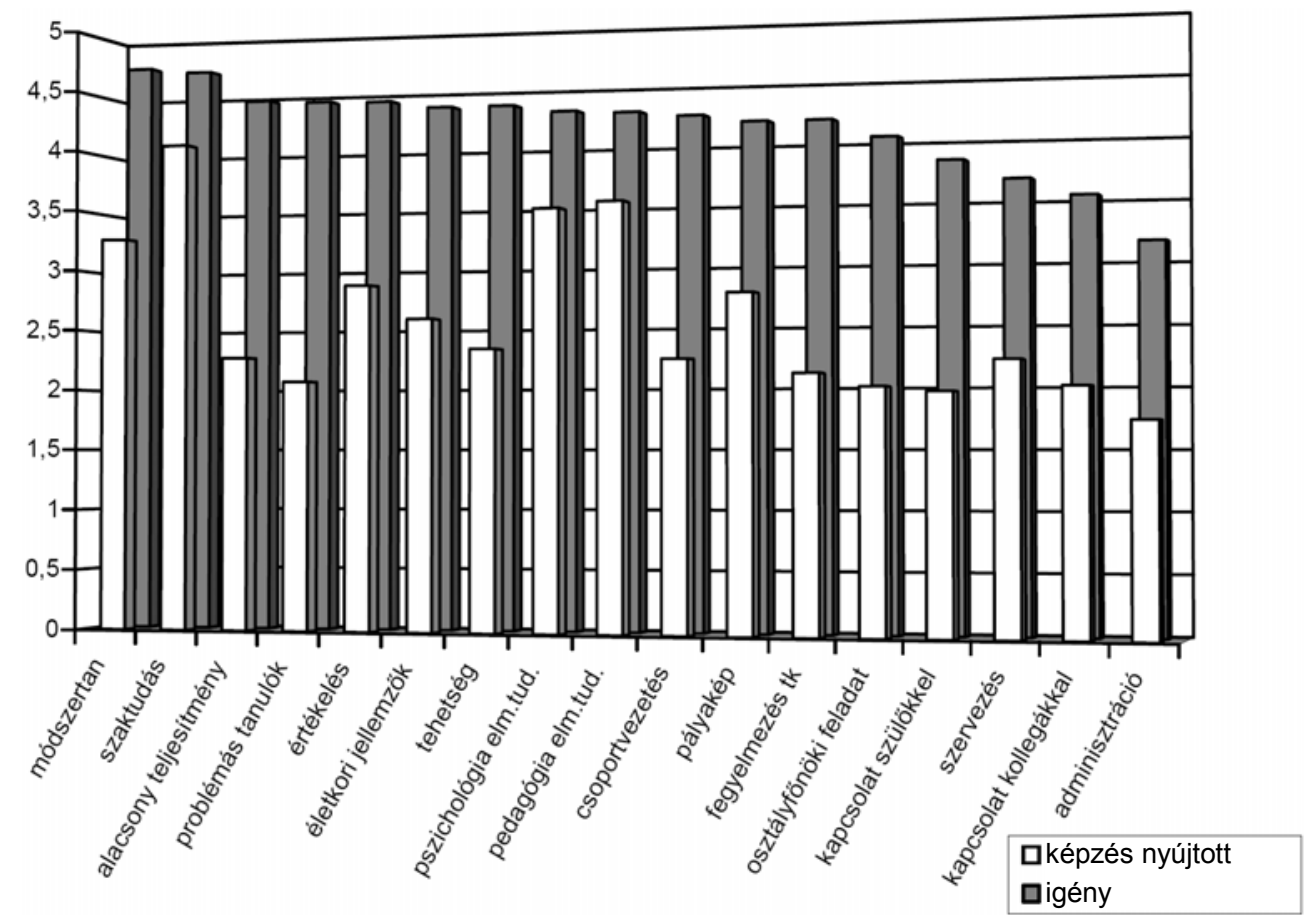

6. ábra: Mit kellene nyújtani a képzésnek, és mit nyújt ténylegesen?

A képzéssel kapcsolatos igények megfelelnek az első kérdésben adott válaszoknak. Legfontosabbnak a tanításhoz szükséges módszertani és szaktudásbeli ismereteket tartják, ezek fontosságának megítélése azonos mértékü. Legkevésbé fontos az adminisztratív és szervezési feladatokra és kollégákkal és szülőkkel való kapcsolattartásra felkészítés. Viszonylag kevésbé fontosnak tartják az osztályfőnöki feladatokra való felkészitést is.

A többi szempont - az alacsony teljesítményü tanulók problémáitól a fegyelmezésig - azonos megítélést kapott. Ebben kiemelendő eredmény az, amire korábban hivatkoztunk már, hogy a pszichológiai és pedagógiai elméleti tudást a felkészítés szerves részének tekintik, az átlagtól eltérő tanulókkal és a csoporttal való bánásmóddal egyenlő mértékben fontosnak ítélik meg.

A képzés hatékonyságát meglehetősen differenciáltan ítélik meg a gyakorló pedagógusok, leginkább az elméleti képzés hatékonyságát ismerik el, a szakmai és pedagógiai valamint pszichológiai tárgyak esetén is. Bár a módszertani képzés öszszességében a 4 . helyen áll, a szakmai tudástól azonban lényesen elmarad (egy mintás $\mathrm{t} \mathrm{p}<0,001)$.

A 7. ábrán a képzésnek a fontossághoz viszonyított hatékonyságát mutatjuk be. 


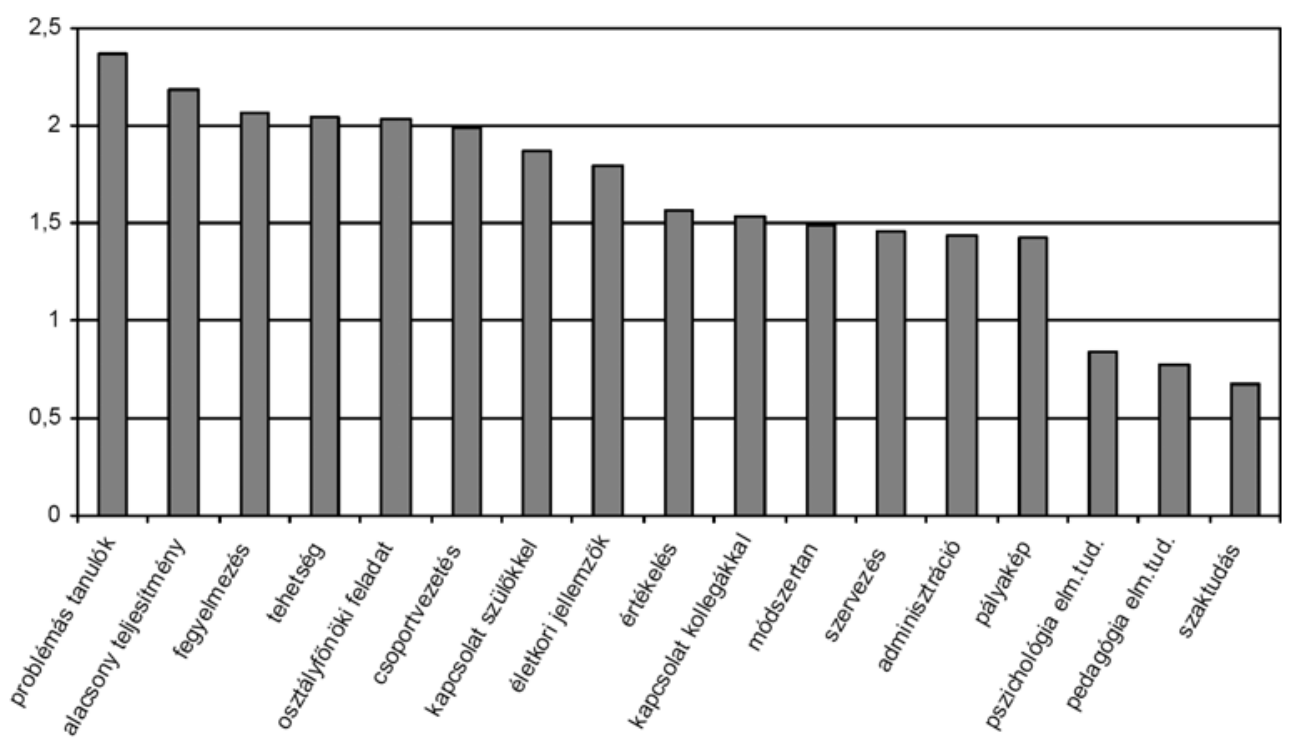

7. ábra: Elégedetlenség mértéke a képzés által megtanítottakkal

A legnagyobb hiányosságokat a problémás tanulókkal való bánásmód területén látják, a legkritikusabb kérdés a magatartási problémák kezelése, de ha nem is ilyen súllyal, de az alacsony teljesítmény is nagy gondot jelent (egy mintás t $\mathrm{p}<0,01$ ).

A feladatkörökkel való elégedetlenség mértékében további két ponton van határozott törésvonal, az életkori jellemzők figyelembevétele és az értékelés, valamint a pályakép és pszichológiai elméleti tudás közt. Így a problémás tanulókkal való bánásmódon túl három nagyobb feladatcsoport rajzolódik ki, az osztály szintủ feladatok (fegyelmezés, csoportvezetés), a módszertani és szervezési feladatok és az elméleti tudás, mint amelyekre egyre nagyobb mértékben felkészített a képzés. Leginkább elégedettek a válaszolók az elméleti felkészítéssel, elsősorban a szakterületi tudásukat tartják közel megfelelőnek - bár ebben is szívesen kapnának többet, és a többihez képest ugyancsak elégedettek a pedagógiai és pszichológiai elméleti tudásukkal.

Érdekes eredmény, hogy az osztályfőnöki feladatokra úgy érzik, hogy nagyon kevéssé készít fel a pedagógusképzés, és ezt annak ellenére állítják, hogy az elvárásaik eléggé visszafogottak e tekintetben.

A válaszok alapján két tanulságot érdemes kiemelni. Egyrészt a gyakorlati képzés erősítését várnák a gyakorló pedagógusok a képzéstől. Másrészt tartalmilag az átlagtól eltérő, magatartási, tanulási problémás, és a tehetséges diákokkal való foglalkozás és az egész osztállyal kapcsolatos probléma, a fegyelmezés terén várnának több segítséget. 


\section{Zárógondolatok}

A pedagógusképzésben, különösen a tanárképzésben hatalmas változások elött áll a magyar felsőoktatás. A változás Janus-arcú, egyszerre rejti magában a nehézségeket és lehetőségeket. A gyakorlatban dolgozók tapasztalatai számos tanulsággal járnak, és úgy gondoljuk, kijelölnek számunkra számos feladatot is. A tanárképzés megújításához úgy véljük, a diákoktól és a pályán levőktől kapható folyamatos visszajelzés adhat további segítséget. A helyzetkép felméréséhez a képzésből frissen kikerülők véleménye is hozzá tartozik, egy következő tanulmányunkban a végzős hallgatókkal folytatott vizsgálatunk tanulságairól számolunk be.

\section{Irodalom}

Boreczky Ágnes (1997): A gyermekkor változó szinterei. Eötvös Kiadó, Budapest.

Cooke B. L., Pang K. C. (1991): Recent research on Beginning Teachers: Studies of Trained and Untrained Novices. Teaching \&Teacher Education, Vol. 7. No. 1. 91-110.

Golnhofer Erzsébet, Falus Iván szerk. (2001): A pedagógusok pedagógiája. Budapest, Nemzeti Tankönyvkiadó.

Gordon, T. (1990): A tanári hatékonyság fejlesztése. A T.E.T-módszer. Budapest, Gondolat Kiadó, 256-262.

Hamachek, D. (1990): Psychology in Teaching, Learning and Growth. 4th. Ed. Allyn and Bacon. 391-424.

Imre Anna 1999: Cigány tanulók a szakmunkásképző iskolában. Educatio 1999. Cigányok 8. évfolyam 2. szám nyár, 286-296.

N. Kollár Katalin (2006): Változó csoportigényekhez alkalmazkodó tréningvezetés. Magyar Pszichológiai Társaság XVII. Pszichológia Nagygyülése, Budapest, Absztrakt kötet 294. o.

N. Kollár Katalin (2008): Csoportigényekhez alkalmazkodó tréningvezetés. Scientia Kiadó, Marosvásárhely, megjelenés alatt.

N. Kollár Katalin, Szabó Éva szerk. (2004): Pszichológia pedagógusoknak. Osiris, Budapest.

M. Tamás Márta, N. Kollár Katalin (2001): A tanulók életmódjának kérdöives vizsgálata. Iskolapszichológia 25, ELTE PPK, Budapest.

Papp János szerk. (2001): A tanári pálya. Szöveggyüjtemény. Debrecen, Kossuth Egyetem Kiadó.

Salamon Zoltán, Széphalmi Ágnes (1988): Pedagógus-életmód és -tevékenység. Korszerü nevelés. Tankönyvkiadó, Budapest.

Szabó Éva (1999) A „kedves”, az „okos” és a „gonosz”, avagy a kedvelt és nem kedvelt tanár képének jellemzöi. Alkalmazott Pszichológia. 1, 31-41.

Szabó Éva (2006): Szeretettel és szigorral. Az iskolai nevelés problémái a szülők és tanárok szemszögéböl. Akadémiai Kiadó, Budapest.

Szivák Judit (1998): A kezdő pedagógus. In: Falus Iván szerk. Didaktika. Budapest, Nemzeti Tankönyvkiadó, 489-512.

Wolters, Ch. A., Daugherty, S. G. (2007): Goal Structures and Teachers' Sense of Efficacy: Their Relation and Association to Teaching Experience and Academic Level. Journal of Educational Psychology, Vol. 99. No. 1. 181-193. 


\section{MELLÉKLET \\ A PEDAGÓGUSOK KÉRDőÍVE}

Kedves Pedagógus Kolléga! A véleményét és tapasztalatait szeretnénk megkérdezni a pedagógus pályával kapcsolatban, a most kidolgozás alatt álló pedagógusképzés számára. A saját gyakorlatban átélt tapasztalatai fontosak számunkra, kérjük a kérdőív kitöltésével segítse munkánkat.

Ahol több válaszlehetőséget adunk meg, kérjük, húzza alá, ahol számokat adunk meg, ott mindig egyet karikázzon be.

A felvétel időpontja: ... 2006.

A válaszadó neme: nő férfi

Kora:

év

Mióta tanít? .......éve

Mi a munkaköre? 1. óvónő

2. tanító,

3. tanár, szakja(i):

4. nem osztálykeretben tanít (fejlesztő)

5. nem tanít órakeretben, de gyerekekkel dolgozik (nevelötanár, napközis)

6. egyéb:

Milyen iskolában dolgozik? óvoda

általános iskola ( 8 osztályos),

gimnázium: $8, \quad 6,4$ osztályos, 12 évfolyamos iskola, szakközépiskola, szakiskola

Nem iskolában dolgozom

Melyik megyében van a munkahelye?

Beosztása, funkciói: nincs van:

igazgató, intézményvezetö/helyettes

munkaközösség-vezető

osztályfönök

gyermek- és ifjúságvédelmi felelős

fakultációt tart, éspedig: 
1. Az Ön személyes tapasztalatai szerint mennyire fontos feladatok az alábbiak, és mennyi időt tud rájuk fordítani

Adjon 1-5 értéket, 1-t, ha egyáltalán nem dolga egy tanárnak, 2-t, ha kevéssé, 3-t, ha közepes mértékben, 4-t, fontos és ötöt, ha elsőrendűen fontos feladat! Majd ítélje meg, hogy a munkaidejéből mennyi időt kell ezekre fordítania, -2-t, ha egyáltalán nem jut rá ideje, $-1-t$ ha kevesebb jut rá, mint kellene, o-t, ha annyit fordít, amennyi szükséges, 1-t, ha többet, mint szeretne, és 2-t, ha túl sok időt kell erre fordítania.

\begin{tabular}{|c|c|c|c|c|c|c|c|c|c|c|}
\hline az Ön tapasztalata szerint: & \multicolumn{5}{|c|}{ fontosság } & \multicolumn{5}{|c|}{ ráforditott munkaidö } \\
\hline tanítás (tervezett foglalkozás) & 1 & 2 & 3 & 4 & 5 & -2 & -1 & 0 & 1 & 2 \\
\hline felkészülés az órákra (foglalkozásra) & 1 & 2 & 3 & 4 & 5 & -2 & -1 & 0 & 1 & 2 \\
\hline tanulók nevelése a tanórán & 1 & 2 & 3 & 4 & 5 & -2 & -1 & 0 & 1 & 2 \\
\hline tanulók nevelése tanórán kívül & 1 & 2 & 3 & 4 & 5 & -2 & -1 & 0 & 1 & 2 \\
\hline kollégákkal kapcsolattartás & 1 & 2 & 3 & 4 & 5 & -2 & -1 & 0 & 1 & 2 \\
\hline adminisztráció & 1 & 2 & 3 & 4 & 5 & -2 & -1 & 0 & 1 & 2 \\
\hline $\begin{array}{l}\text { tehetséges tanulókkal foglalkozás } \\
\text { tanórán }\end{array}$ & 1 & 2 & 3 & 4 & 5 & -2 & -1 & 0 & 1 & 2 \\
\hline $\begin{array}{l}\text { tehetséges tanulókkal foglalkozás } \\
\text { tanórán kívül }\end{array}$ & 1 & 2 & 3 & 4 & 5 & -2 & & 0 & 1 & 2 \\
\hline $\begin{array}{l}\text { átlagosnál gyengébben teljesítőkkel } \\
\text { foglalkozás tanórán }\end{array}$ & 1 & 2 & 3 & 4 & 5 & -2 & -1 & 0 & 1 & 2 \\
\hline $\begin{array}{l}\text { átlagosnál gyengébben teljesítőkkel } \\
\text { foglalkozás tanórán kívül }\end{array}$ & 1 & 2 & 3 & 4 & 5 & -2 & -1 & 0 & 1 & 2 \\
\hline tanításon kívüli szervezés (kirándulás) & 1 & 2 & 3 & 4 & 5 & -2 & -1 & 0 & 1 & 2 \\
\hline $\begin{array}{l}\text { tanítással kapcsolatos szervezés } \\
\text { (fénymásolás, tankönyvrendelés) }\end{array}$ & 1 & 2 & 3 & 4 & 5 & -2 & -1 & 0 & 1 & 2 \\
\hline szülökkel kapcsolattartás & 1 & 2 & 3 & 4 & 5 & -2 & -1 & 0 & 1 & 2 \\
\hline önművelés, továbbképzés & 1 & 2 & 3 & 4 & 5 & -2 & -1 & 0 & 1 & 2 \\
\hline
\end{tabular}


2. Az alábbi tulajdonságok mind hasznosak egy tanárnak. Az Ön tapasztalatai szerint a tanári pálya gyakorlásához ezekre mennyire van szükség? Majd kérjük, gondolja végig, milyen mértékben fejleszthetőek ezek a tulajdonságok, és végül azt jelölje meg az 5 fokozat egyikével, hogy az Ön esetében a föiskolai/egyetemi képzés mennyire fejlesztette ezeket? (1 most is a legkisebb, 5 a legnagyobb érték)

\begin{tabular}{|c|c|c|c|c|c|c|c|c|c|c|c|c|c|c|c|}
\hline \multirow[b]{2}{*}{$\begin{array}{l}\text { elkötelezettség, } \\
\text { pályaszeretet }\end{array}$} & \multicolumn{5}{|c|}{ fontosság } & \multicolumn{5}{|c|}{$\begin{array}{c}\text { mennyire } \\
\text { fejleszthetö? }\end{array}$} & \multicolumn{5}{|c|}{$\begin{array}{l}\text { mennyire segitette } \\
\text { a képzés a fejlödését? }\end{array}$} \\
\hline & 1 & 2 & 3 & 4 & 5 & 1 & 2 & 3 & 4 & 5 & 1 & 2 & 3 & 4 & 5 \\
\hline empátia & 1 & 2 & 3 & 4 & 5 & 1 & 2 & 3 & 4 & 5 & 1 & 2 & 3 & 4 & 5 \\
\hline $\begin{array}{l}\text { önreflexiós (önelem- } \\
\text { zési, önkritikai és } \\
\text { belátási) készség }\end{array}$ & 1 & 2 & 3 & 4 & 5 & 1 & 2 & 3 & 4 & 5 & 1 & 2 & 3 & 4 & 5 \\
\hline $\begin{array}{l}\text { érzelmi kontroll } \\
\text { képessége }\end{array}$ & 1 & 2 & 3 & 4 & 5 & 1 & 2 & 3 & 4 & 5 & 1 & 2 & 3 & 4 & 5 \\
\hline $\begin{array}{l}\text { szabálytudat, } \\
\text { szabálykövetés és } \\
\text {-alkotás képessége }\end{array}$ & 1 & 2 & 3 & 4 & 5 & 1 & 2 & 3 & 4 & 5 & 1 & 2 & 3 & 4 & 5 \\
\hline $\begin{array}{l}\text { szociális alkalmazko- } \\
\text { dási készség }\end{array}$ & 1 & 2 & 3 & 4 & 5 & 1 & 2 & 3 & 4 & 5 & 1 & 2 & 3 & 4 & 5 \\
\hline $\begin{array}{l}\text { új helyzetekhez való } \\
\text { alkalmazkodás } \\
\text { készsége }\end{array}$ & 1 & 2 & 3 & 4 & 5 & 1 & 2 & 3 & 4 & 5 & 1 & 2 & 3 & 4 & 5 \\
\hline $\begin{array}{l}\text { kezdeményezési és } \\
\text { vállalkozási szellem }\end{array}$ & 1 & 2 & 3 & 4 & 5 & 1 & 2 & 3 & 4 & 5 & 1 & 2 & 3 & 4 & 5 \\
\hline minőségigény & 1 & 2 & 3 & 4 & 5 & 1 & 2 & 3 & 4 & 5 & 1 & 2 & 3 & 4 & 5 \\
\hline $\begin{array}{l}\text { nyitottság más } \\
\text { kultúrák, szokások } \\
\text { megértésére }\end{array}$ & 1 & 2 & 3 & 4 & 5 & 1 & 2 & 3 & 4 & 5 & 1 & 2 & 3 & 4 & 5 \\
\hline sikerorientáció & 1 & 2 & 3 & 4 & 5 & 1 & 2 & 3 & 4 & 5 & 1 & 2 & 3 & 4 & 5 \\
\hline vezetési képesség & 1 & 2 & 3 & 4 & 5 & 1 & 2 & 3 & 4 & 5 & 1 & 2 & 3 & 4 & 5 \\
\hline $\begin{array}{l}\text { nyitottság és } \\
\text { elfogadás a sérültek, } \\
\text { betegség stb. iránt }\end{array}$ & 1 & 2 & 3 & 4 & 5 & 1 & 2 & 3 & 4 & 5 & 1 & 2 & 3 & 4 & 5 \\
\hline etikai elkötelezettség & 1 & 2 & 3 & 4 & 5 & 1 & 2 & 3 & 4 & 5 & 1 & 2 & 3 & 4 & 5 \\
\hline $\begin{array}{l}\text { jó magyarázási } \\
\text { képesség }\end{array}$ & 1 & 2 & 3 & 4 & 5 & 1 & 2 & 3 & 4 & 5 & 1 & 2 & 3 & 4 & 5 \\
\hline
\end{tabular}




\begin{tabular}{|c|c|c|c|c|c|c|c|c|c|c|c|c|c|c|c|}
\hline \multirow[b]{2}{*}{$\begin{array}{l}\text { együttműködő } \\
\text { készség }\end{array}$} & \multicolumn{5}{|c|}{ fontosság } & \multicolumn{5}{|c|}{$\begin{array}{c}\text { mennyire } \\
\text { fejleszthetö? }\end{array}$} & \multicolumn{5}{|c|}{$\begin{array}{c}\text { mennyire segitette } \\
\text { a képzés a fejlödését? }\end{array}$} \\
\hline & 1 & 2 & 3 & 4 & 5 & 1 & 2 & 3 & 4 & 5 & 1 & 2 & 3 & 4 & 5 \\
\hline kiegyensúlyozottság & 1 & 2 & 3 & 4 & 5 & 1 & 2 & 3 & 4 & 5 & 1 & 2 & 3 & 4 & 5 \\
\hline türelem & 1 & 2 & 3 & 4 & 5 & 1 & 2 & 3 & 4 & 5 & 1 & 2 & 3 & 4 & 5 \\
\hline pozitív önértékelés & 1 & 2 & 3 & 4 & 5 & 1 & 2 & 3 & 4 & 5 & 1 & 2 & 3 & 4 & 5 \\
\hline $\begin{array}{l}\text { bizalom a gyermek } \\
\text { fejlődőképességében }\end{array}$ & 1 & 2 & 3 & 4 & 5 & 1 & 2 & 3 & 4 & 5 & 1 & 2 & 3 & 4 & 5 \\
\hline hitelesség & 1 & 2 & 3 & 4 & 5 & 1 & 2 & 3 & 4 & 5 & 1 & 2 & 3 & 4 & 5 \\
\hline következetesség & 1 & 2 & 3 & 4 & 5 & 1 & 2 & 3 & 4 & 5 & 1 & 2 & 3 & 4 & 5 \\
\hline kreativitás, ötletesség & 1 & 2 & 3 & 4 & 5 & 1 & 2 & 3 & 4 & 5 & 1 & 2 & 3 & 4 & 5 \\
\hline $\begin{array}{l}\text { gyors reagálás a } \\
\text { váratlan helyzetekre }\end{array}$ & 1 & 2 & 3 & 4 & 5 & 1 & 2 & 3 & 4 & 5 & 1 & 2 & 3 & 4 & 5 \\
\hline $\begin{array}{l}\text { határozottság, } \\
\text { döntésképesség }\end{array}$ & 1 & 2 & 3 & 4 & 5 & 1 & 2 & 3 & 4 & 5 & 1 & 2 & 3 & 4 & 5 \\
\hline $\begin{array}{l}\text { jó kommunikációs } \\
\text { készség }\end{array}$ & 1 & 2 & 3 & 4 & 5 & 1 & 2 & 3 & 4 & 5 & 1 & 2 & 3 & 4 & 5 \\
\hline
\end{tabular}

3. Önnek mi segített a pedagógusi pályához szükséges képességek kialakításában? 0 . nem volt ilyen tapasztalatom; 1. egyáltalán nem; 2 . kevéssé; 3. közepesen 4. nagymértékben; 5. teljes mértékben ez segített

\begin{tabular}{|c|c|c|c|c|c|c|}
\hline családi neveltetés, gyerekkori tapasztalatok a családban & 0 & 1 & 2 & 3 & 4 & 5 \\
\hline adottságok (veleszületett képességek) & 0 & 1 & 2 & 3 & 4 & 5 \\
\hline saját iskolai tanítók/tanárok jó példája & 0 & 1 & 2 & 3 & 4 & 5 \\
\hline $\begin{array}{l}\text { gyakorlati tapasztalatok gyerekekkel a képzéstől függetlenül } \\
\text { (saját tanítvány, csoportvezetés stb.) }\end{array}$ & 0 & 1 & 2 & 3 & 4 & 5 \\
\hline \multicolumn{7}{|l|}{ a képzés során: } \\
\hline helyzetgyakorlatok & 0 & 1 & 2 & 3 & 4 & 5 \\
\hline hospitálás & 0 & 1 & 2 & 3 & 4 & 5 \\
\hline tanítási gyakorlat hallgatóként & 0 & 1 & 2 & 3 & 4 & 5 \\
\hline mikrotanítás & 0 & 1 & 2 & 3 & 4 & 5 \\
\hline $\begin{array}{r}\text { interjú, személyes tapasztalat felnőttekkel } \\
\text { (tanárokkal, szülőkkel) } \\
\end{array}$ & 0 & 1 & 2 & 3 & 4 & 5 \\
\hline gyakorlati feladatok gyerekekkel (esettanulmány) & 0 & 1 & 2 & 3 & 4 & 5 \\
\hline pszichológia előadások & 0 & 1 & 2 & 3 & 4 & 5 \\
\hline
\end{tabular}




\begin{tabular}{|c|c|c|c|c|c|c|}
\hline pedagógia előadások & 0 & 1 & 2 & 3 & 4 & 5 \\
\hline tanár szakos szemináriumok & 0 & 1 & 2 & 3 & 4 & 5 \\
\hline tréning (önismereti, képességfejlesztő stb.) & 0 & 1 & 2 & 3 & 4 & 5 \\
\hline tanármodellek a főiskolán/egyetemen & 0 & 1 & 2 & 3 & 4 & 5 \\
\hline \multicolumn{7}{|l|}{ végzés után: } \\
\hline a pedagógusként szerzett tapasztalatok & 0 & 1 & 2 & 3 & 4 & 5 \\
\hline kollegák segítsége & 0 & 1 & 2 & 3 & 4 & 5 \\
\hline pedagógus-továbbképzés & 0 & 1 & 2 & 3 & 4 & 5 \\
\hline egyéb: & 0 & 1 & 2 & 3 & 4 & 5 \\
\hline
\end{tabular}

4. Milyen mértékben készítette fel a főiskola/egyetem?

(1. egyáltalán nem-5. teljes mértékben)

\begin{tabular}{|c|c|c|c|c|c|c|c|c|c|c|}
\hline \multirow[b]{2}{*}{ szakmai tudásszint } & \multicolumn{5}{|c|}{$\begin{array}{l}\text { saját képzése mit } \\
\text { nyújtott? }\end{array}$} & \multicolumn{5}{|c|}{$\begin{array}{c}\text { mennyire kellene } \\
\text { a képzésnek } \\
\text { nyújtania? }\end{array}$} \\
\hline & 1 & 2 & 3 & 4 & 5 & 1 & 2 & 3 & 4 & 5 \\
\hline $\begin{array}{l}\text { módszertani ismeretek (mit hogyan } \\
\text { tanítsunk) }\end{array}$ & 1 & 2 & 3 & 4 & 5 & 1 & 2 & 3 & 4 & 5 \\
\hline $\begin{array}{l}\text { pedagógiai elméleti tudás, didaktika } \\
\text { szemlélet }\end{array}$ & 1 & 2 & 3 & 4 & 5 & 1 & 2 & 3 & 4 & 5 \\
\hline pszichológia elméleti tudás, szemlélet & 1 & 2 & 3 & 4 & 5 & 1 & 2 & 3 & 4 & 5 \\
\hline reális pályakép (milyen elvárások lesznek) & 1 & 2 & 3 & 4 & 5 & 1 & 2 & 3 & 4 & 5 \\
\hline $\begin{array}{l}\text { különböző életkorú tanulókkal való } \\
\text { bánásmód }\end{array}$ & 1 & 2 & 3 & 4 & 5 & 1 & 2 & 3 & 4 & 5 \\
\hline tehetséges tanulókkal való bánásmód & 1 & 2 & 3 & 4 & 5 & 1 & 2 & 3 & 4 & 5 \\
\hline átlag alatt teljesítőkkel való bánásmód & 1 & 2 & 3 & 4 & 5 & 1 & 2 & 3 & 4 & 5 \\
\hline $\begin{array}{l}\text { érzelmi, magatartási problémás tanulókkal } \\
\text { való bánásmód }\end{array}$ & 1 & 2 & 3 & 4 & 5 & 1 & 2 & 3 & 4 & 5 \\
\hline osztály, mint csoport vezetése & 1 & 2 & 3 & 4 & 5 & 1 & 2 & 3 & 4 & 5 \\
\hline fegyelmezési módszerek & 1 & 2 & 3 & 4 & 5 & 1 & 2 & 3 & 4 & 5 \\
\hline osztályfőnöki feladatok & 1 & 2 & 3 & 4 & 5 & 1 & 2 & 3 & 4 & 5 \\
\hline tanulók értékelésének módja & 1 & 2 & 3 & 4 & 5 & 1 & 2 & 3 & 4 & 5 \\
\hline kapcsolat a kollegákkal & 1 & 2 & 3 & 4 & 5 & 1 & 2 & 3 & 4 & 5 \\
\hline szülőkkel kapcsolattartás & 1 & 2 & 3 & 4 & 5 & 1 & 2 & 3 & 4 & 5 \\
\hline szervezési feladatok & 1 & 2 & 3 & 4 & 5 & 1 & 2 & 3 & 4 & 5 \\
\hline adminisztráció & 1 & 2 & 3 & 4 & 5 & 1 & 2 & 3 & 4 & 5 \\
\hline
\end{tabular}


5. Milyen módszereket javasolna az eddig szóba kerülteken kívül a tanárképzés hatékonyabbá tétele érdekében?

6. A körülöttünk levő világ, és a felnövő generáció változásáról bizonyára vannak tapasztalatai. Kérjük, végezetül írja le, milyen módon lehet felkészíteni ezekre a (sok szempontból előre nem látható) változásokra a leendő pedagógusokat! 